\title{
The Development of a National Interregional Transport Matrix for Respirable Particulates
}

\section{October 1979}

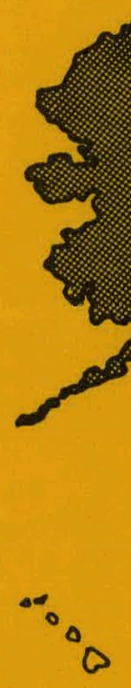

Prepared for the

U.S. Department of Energy Assistant Secretary for Environment Office of Technology Impacts under Contract EY-76-C-06-1830

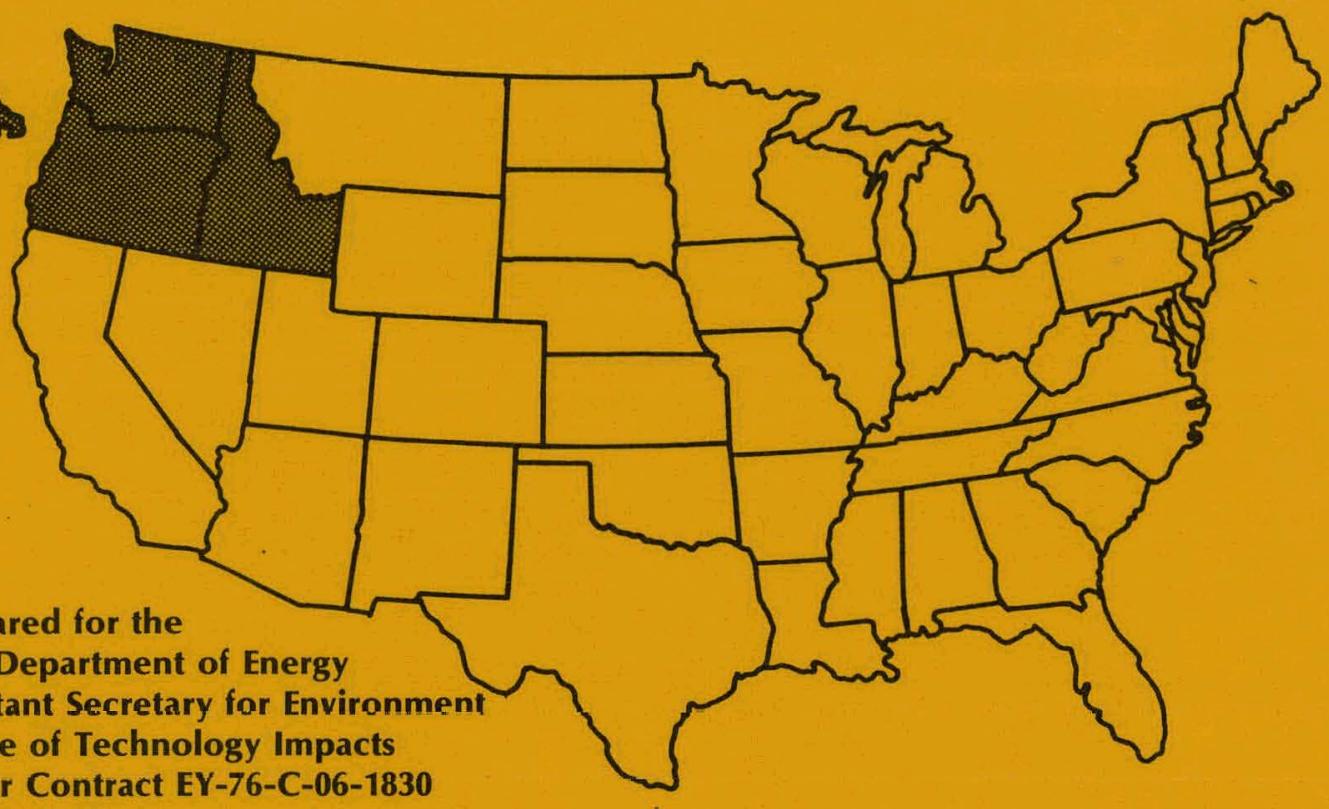

Richard Ball, Project Monitor

Pacific Northwest Laboratory

Operated for the U.S. Department of Energy

by Battelle Memorial Institute

\section{* Battelle}




\section{DISCLAIMER}

This report was prepared as an account of work sponsored by an agency of the United States Government. Neither the United States Government nor any agency Thereof, nor any of their employees, makes any warranty, express or implied, or assumes any legal liability or responsibility for the accuracy, completeness, or usefulness of any information, apparatus, product, or process disclosed, or represents that its use would not infringe privately owned rights. Reference herein to any specific commercial product, process, or service by trade name, trademark, manufacturer, or otherwise does not necessarily constitute or imply its endorsement, recommendation, or favoring by the United States Government or any agency thereof. The views and opinions of authors expressed herein do not necessarily state or reflect those of the United States Government or any agency thereof. 


\section{DISCLAIMER}

Portions of this document may be illegible in electronic image products. Images are produced from the best available original document. 


\title{
NOTICE
}

This report was prepared as an account of work sponsored by the United States Government. Neither the United States nor the Department of Energy, nor any of their employees, nor any of their contractors, subcontractors, or their employees, makes any warranty, express or implied, or assumes any legal liability or responsibility for the accuracy, completeness or usefulness of any information, apparatus, product or process disclosed, or represents that its use would not infringe privately owned rights.

The views, opinions and conclusions contained in this report are those of the contractor and do not necessarily represent those of the United States Government or the United States Department of Energy.

\author{
PACIFIC NORTHWEST LABORATORY \\ operated by \\ BATTELLE \\ for the \\ UNITED STATES DEPARTMENT OF ENERGY \\ Under Contract EY-76-C-06-1830
}

Printed in the United States of A
Available from
National Technical Information Sert
United States Department of Com
5285 Port Royal Road
Springfield, Virginia 22151
Price: Printed Copy \$ $\$$; Microfi

•Pages


THE DEVELOPMENT OF A NATIONAL INTERREGIONAL TRANSPORT MATRIX FOR RESPIRABLE PARTICULATES

Prepared for the U.S. Department of Energy Assistant Secretary for Environment Office of Technology Impacts

under Contract EY-76-C-06-1830

Richard Ball, Project Monitor Environmental Impacts Division

Prepared by $\begin{aligned} & \text { W. J. Eadie } \\ & \text { W. E. Davis }\end{aligned}$

October 1979

Pacific Northwest Laboratory Richland, Washington 99352 
THIS PAGE

\section{WAS INTENTIONALLY \\ LEFT BLANK}


SUMMARY AND ACKNOWLEDGMENTS

The Pacific Northwest Laboratory (PNL) long-range transport model was used to produce monthly, average air concentrations of respirable particulates produced by 86 unit emission sources located at points on a grid spanning the continental United States. These monthly assessments were interpolated to provide monthly, average air concentrations resulting from a unit source located at the centroid of each of 238 Air Quality Control Regions (AQCR). The air concentration field from each emitter AQCR was averaged over each receptor AQCR to produce a population-weighted, average air concentration of respirable particulates. The final product is a matrix of the monthly, average air concentration of respirable particulates over each receptor AQCR resulting from the unit emission from each emitter AQCR. Matrices were generated using meteorological data from the months of January, Apri1, July and October 1974 .

The program was undertaken to develop a useful method of assessing the air quality impacts resulting from various predicted energy-technology use scenarios. The AQCR-to-AQCR matrix can be used with any siting scenario of energy technologies to predict the air quality impact on any AQCR of the projected emissions from other AQCRs by multiplying the matrix elements by the projected emissions and summing the products over the emitting AQCRs. The matrix approach will allow the ranking of the air quality impacts of various siting scenarios of energy technology use without rerunning the long-range transport model.

The work reported here was conducted under the direction of and with funding from the U.S. Department of Energy, Office of Technology Impacts, Environmental Impact Division. The authors wish to acknowledge the support of the Division and the guidance of the DOE project monitor, Mr. Richard Ball.

The authors also wish to thank W. F. Sandusky for his comments and suggestions concerning the program and D. R. Drewes who provided the computer graphics for this report. 


\section{THIS PAGE}

\section{WAS INTENTIONALLY \\ LEFT BLANK}




\section{CONTENTS}

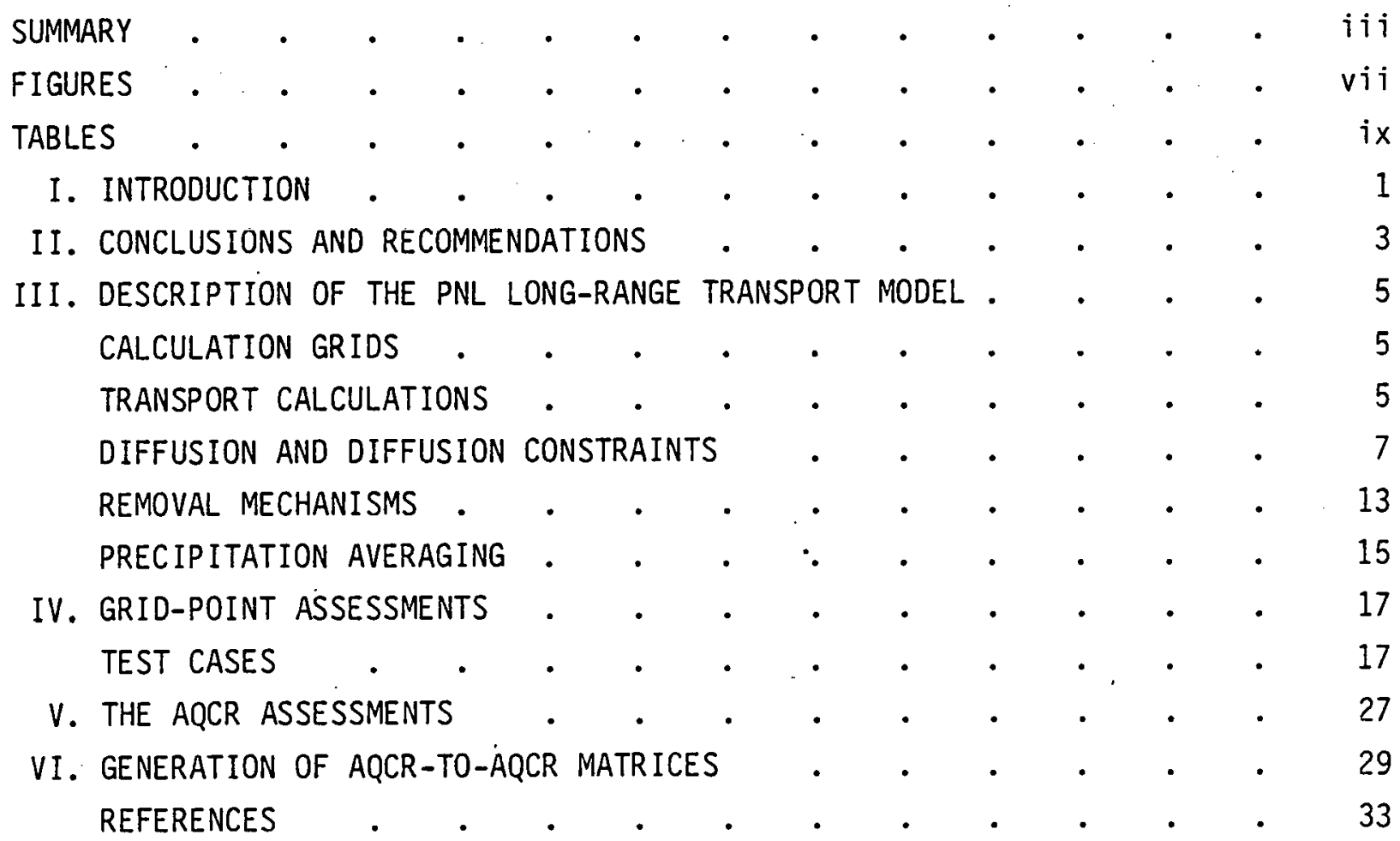


THIS PAGE

WAS INTENTIONALLY

LEFT BLANK 


\section{FIGURES}

1 PNL Advection Grid and Grid-Point Source Locations . $\quad$ • . 6

2 Daytime Illustration of Stability Definition and Vertical

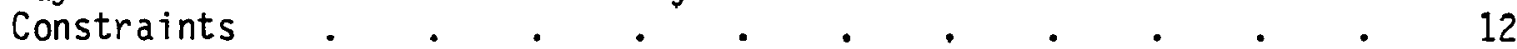

3 Source Location in Four Corners Region and Four Surrounding

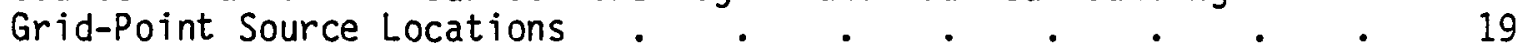

4 Average Particulate Air Concentrations for Single Source in Four Corners Region, $\mu \mathrm{g} \mathrm{m}^{-3}$ (July 1974) . . . . . 20

5 Average Particulate Air Concentrations for Single Source in Four Corners Region Interpolated From Assessments for Sources at Four Surrounding Grid Points, $\mu \mathrm{g} \mathrm{m}^{-3}$ (July 1974) • . . 20

6 Average Partigulate Depositions for Single Source in Four Corners Region, $\mathrm{mg} \mathrm{m}^{-2}$ (July 1974) . . . . . . . . . 21

7 . Average Particulate Depositions for Single Source in Four Corners Region Interpolated from Assessments for Sources at Four Surrounding Grid Points, $\mathrm{mg} \mathrm{m}^{-2}$ (July 1974) . . . . 21

8 Average Particulate Air Concentrations for an RIIA Utility 1985 Scenario Computed Using Hourly Precipitation for Wet Removal, ug $\mathrm{m}^{-3}$ (July 1974)

9 Average Particulate Air Concentrations for an RIIA Utility 1985 Scenario Interpolated from Grid-Point Assessments Using Hourly Precipitation for Wet Removal, $\mu \mathrm{g} \mathrm{m}^{-3}$. (July 1974)

10 Average Particulate Air Concentrations for an RIIA Utility 1985 Scenario Interpolated from Grid-Point Assessments Using TimeAveraged Precipitation for Wet Removal, $\mu \mathrm{g} \mathrm{m}^{-3}$ (July 1974)

11 Average Particulate Deposition for a RIIA Utility 1985 Scenario, Computed Using Hourly Precipitation for Wet Removal, $\mathrm{mg} \mathrm{m} \mathrm{m}^{-2}$ (July 1974)

12 Average Particulate Deposition for a RIIA Utility 1985 Scenario, Interpolated from Grid-2Point Assessments Using Hourly Precipitation for Wet Removal, $\mathrm{mg} \mathrm{m}^{-2}$ (July 1974)

13 Average Particulate Deposition for an RIIA Utility 1985 Scenario Interpolated from Grid-Point Assessments Using Time-Averaged Precipitation for Wet Removal, $\mathrm{mg} \mathrm{m}^{-2}$ (July 1974) . . 
THIS PAGE

WAS INTENTIONALLY

LEFT BLANK 


\section{TABLES}

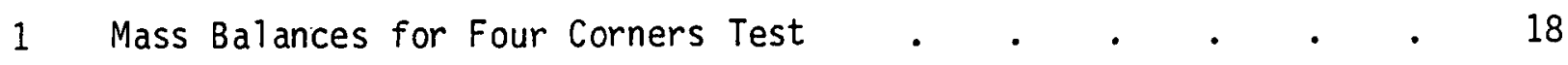

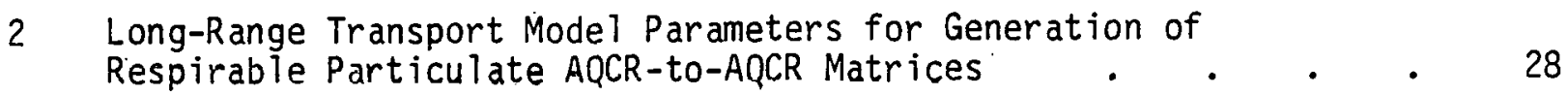

3 Monthly Variations in Long-Range Transport AQCR-to-AQCR Matrix Elements for Respirable Particulates as Calculated Using Meteorological Data from Four Months in 1974 


\section{INTRODUCTION}

One objective of the Regional Assessment Program (RAP) is to develop a useful tool for the Division of Environmental Impacts of the Department of Energy to assess the air quality impacts resulting from various predicted energy-technology use scenarios. The tool will provide a basis for future National Energy Plan evaluation.

To accomplish this objective, pollutant transport and dispersion calculations were made by use of the Pacific Northwest Laboratory (PNL) Iong-range transport model. The pollutant of concern is emitted particulates in the respirable size range. To make the results most useful, a unit emission source was placed at the centroid of each Air Quality Control Region $(A Q C R)^{(a)}$, and the air quality impact on each AQCR was computed. The model outputs a matrix of the average respirable particulate concentration for each receptor AQCR resulting from the unit respirable particulate emission from each AQCR.

The superposition of air quality impacts from different emission sources is permitted in the PNL long-range transport model. Therefore, the AQCR-toAQCR matrix can be used with any siting scenario of energy technologies to predict the air quality impact on any AQCR of the projected emissions from other AQCRs by multiplying the appropriate matrix element by the projected emissions and summing over the emitting AQCRs.

The PNL long-range transport model is discussed in some detail in Section III. The PNL regional-scale transport, transformation, and removal model was developed by Wendell et al. (1976) and was adapted for use in the western United States by Renne et a1. (1978) and Sandusky et al. (1979). Sensitivity and verification studies with the model have been conducted by Powell et al. (1979) and D. J. McNaughton (PNL) for sulfur dioxide and sulfur sulfate air concentrations and depositions in the northeastern United States.

(a) The Federal government has designated 238 regions of the 50 states, the District of Columbia, and United States territories as Air Quality Control Regions. These Federally administered regions are necessary or appropriate for the attainment and maintenance of ambient air quality standards. 
Instead of performing a monthly assessment for each emission source or group of emission sources as in the conventional operation of the PNL model, individual monthly assessments were carried out for 86 unit sources of respirable particulates located at regular grid points spanning the United States (see Figure 1 on page 6). A monthly assessment for a source located at the centroid of an AQCR was calculated by assigning a weight to the assessments performed for the most part on the four nearest grid points to the source location based on the inverse square of the distance from the grid points to the source location. The weighted grid-point assessments were then superimposed on the source location and summed to obtain a monthly average air concentration field resulting from the unit source located at the centroid of the AQCR. These techniques are discussed in Sections IV and $V$.

To convert these monthly, average air concentration fields into air quality impacts for each receptor AQCR, a computer file was developed that contained 1) the grid boxes wholly or partially within each of the AQCRs, and 2) a population weight for each such box for each AQCR. By using county-level information from two computer files residing on the Brookhaven National Laboratory (BNL) computer system, the file was developed in which the weight of a grid box contributing to a receptor $A Q C R$ is equal to the ratio of the population in the box residing within the receptor AQCR to the total population residing within the AQCR. BNL population projections for 1985 were used to obtain the population weights. The development of national AQCR-to-AQCR long-range matrices for respirable particulates is discussed in Section VI. 


\section{CONCLUSIONS AND RECOMMENDATIONS}

A new method is presented for making pollutant impact assessments with the Pacific Northwest Laboratory (PNL) regional-scale computer model. The method uses assessments at grid intersects on the National Meteorological Center (NMC) grid. These assessments are weighted by the inverse square of the distance from the grid points to the source point and are superimposed and added together to produce an estimated assessment for that source.

The method allows the user to make numerous AQCR-to-AQCR air quality assessments from relatively few grid-point assessments, thus realizing a saving on computer cost, and also allows the user to form a data bank of these grid-point assessments. The data bank, in turn, allows the user to add additional grid-point assessments in areas where greater detail is necessary.

In order to test this new technique, two case studies were performed. The first was for a single-source and grid-source emission at Four Corners using July 1979 meteorological data: The results showed good agreement for the centerline concentrations. The grid source assessment tended to smooth the concentration fields, causing overestimations in areas of low concentrations. The second case, using Juily 1974 meteorological data, was run for the western United States using a previous multisource assessment for comparison purposes. Two computer runs were made. The first run was made using hourly precipitation; the second run was made using time-averaged precipitation. The result from this study showed good centerline concentrations for the grid assessments. However, again the grid assessments tended to smooth the patterns.

Based on the results from the two case studies, a decision was made to use the technique in computing the effects of respirable particles from all of the Air Quality Control Regions (AQCR) on all other AQCRs. Results of this study for 4 months (January, April, July, and October 1974) are presented. The results are presented in the form of two air concentration matrices. The first is a matrix of the effect of an emission from one AUCR on all ulher. AQCRs; the second is a matrix of the effects of emissions from all AQCRs on an 
AQCR. Both air concentration matrices were formed based on a constant emission rate of 1 kiloton/yr for each AQCR.

In assessment work there are many areas open to improvement. One would like to take into account the three-dimensional aspect of airflow, especially in the West where large changes in terrain height occur and in the vertical motion during frontal storm passages (Davis. 1979). This feature would also be of advantage when scavenging is investigated so that the wet deposition could be separated into below-cloud and incloud scavenging.

Along the West coast where a marine climate with low potential temperatures prevail, it is difficult in general for airflow to be moved vertically over the mountain barriers into regions with high potential temperatures. A model with vertical motions and ability to distinguish air masses by their differences in potential temperature would aid in assessment work and should be used in sensitivity studies.

There are other areas where sensitivity studies should be performed. Significant differences in the results can occur as a result of reported variations in the parameterization of dry and wet deposition, and the use of time-averaged precipitation and horizontal diffusion. These should be investigated. Also, studies should be continued to establish what time period is necessary to achieve a reasonable approximation to climatological conditions. This would insure, that the results are simply not variations on the mean conditions but represent the mean condition. 


\section{DESCRIPTION OF THE PNL LONG-RANGE TRANSPORT MODEL}

\section{CALCULATION GRIDS}

The grid system in the PNL long-range model adopted for this program is based upon the National Meteorological Center (NMC) Northern Hemisphere grid. The NMC grid is a regularly spaced grid laid out on a polar stereographic projection. The PNL advection grid (see Figure 1) upon which layer-averaged winds are mapped every $12 \mathrm{hr}$ is a subset of the NMC grid and spans the United States and adjacent areas. The dimensions of the PNL grid are 14 NMC grid units in the $X$ direction and 12 NMC grid units in the $Y$ direction with the origin at $X=13.0$ and $Y=4.0$. The sampling grid upon which pollutant air concentrations and depositions are predicted has linear dimensions $1 / 10$ the advection spacing making a $140 \times 120$ array of grid squares. The precipitation data that is used in the wet-removal calculations in the model is also mapped on the sampling grid. The sampling grid spacing is approximately $38 \mathrm{~km}$ at $60^{\circ} \mathrm{N}$ and $32 \mathrm{~km}$ at $35^{\circ} \mathrm{N}$ latitude.

\section{TRANSPORT CALCULATIONS}

Trajectories are simulated for plume elements released hourly from an emission source location. The unit emission rate at the source position determines the initial respirable particulate mass of each plume element. Subsequent horizontal transport of these plume elements is in hourly steps using the layer-averaged winds at each advection-grid intersection point. An objective analysis scheme developed for mesoscale purposes (Wendell 1972) interpolates wind data in space and time to provide the hourly winds at each particle position. The current transport scheme has no vertical component. It is assumed that the concentrations of respirable particulates are averaged over a time period in which the effects of vertical atmospheric processes can be adequately expressed by the parameterized vertical component of diffusion and by the mixing depth constraints. It is also assumed that the effects of vertical transport on horizontal transport can be neglected over the long assessment time period. 
$a$

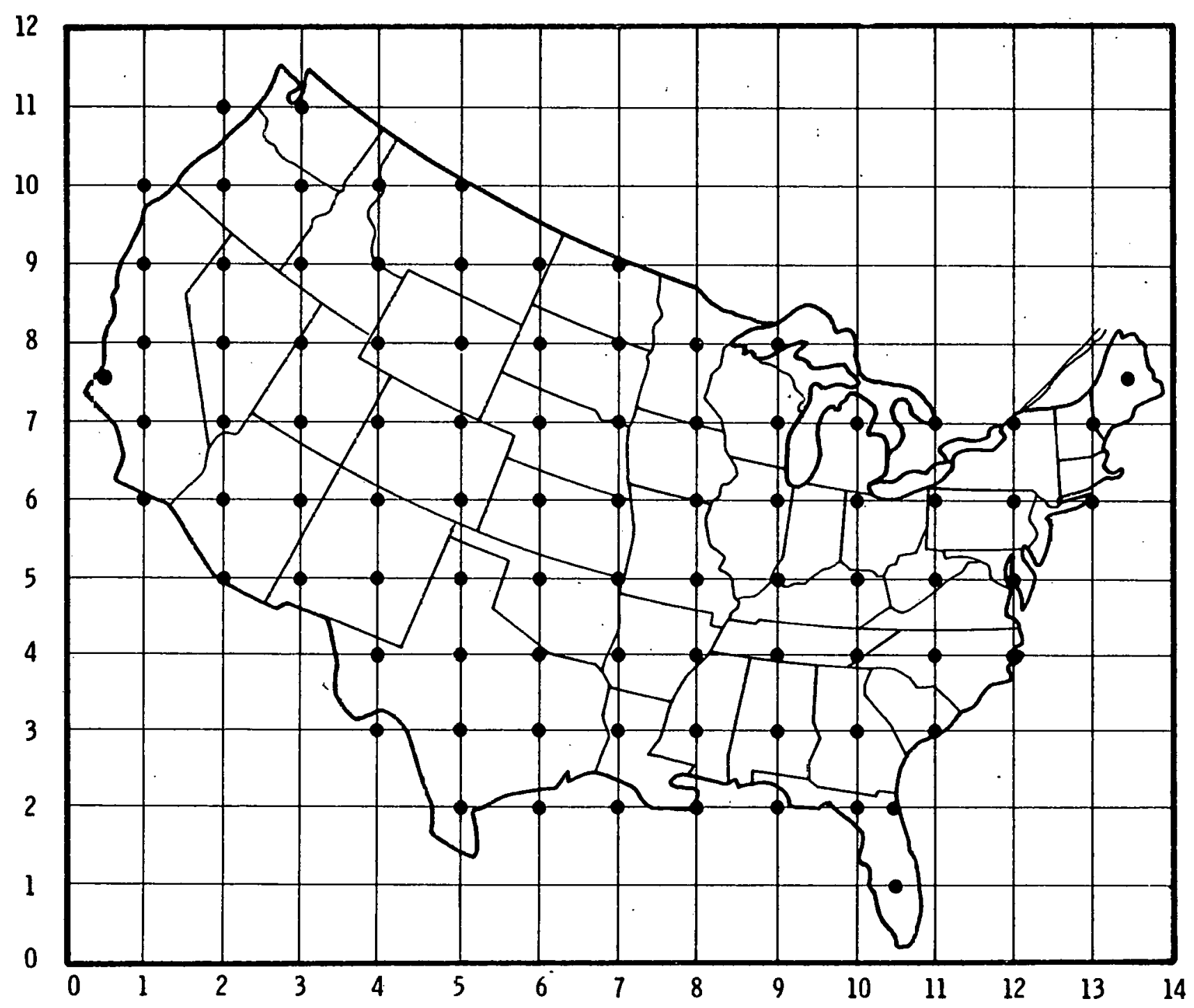

FIGURE 1. PNL Advection Grid and Grid-Point Source Locations 


\section{DIFFUSION AND DIFFUSION CONSTRAINTS}

The following assumptions are made regarding atmospheric diffusion:

1. Horizontal diffusion is a function of synoptic-scale wind variation on ly. Tennekes (1974), Bolin and Persson (1975), and Prahm and Christensen (1977) support this assumption. All state that either horizontal turbulent diffusion about the plume center line is relatively unimportant or that it is less important than plume meandering.

2. The vertical-turbulent diffusion parameterization is a function of stability in a specified diurnal cycle for all plume elements within the daytime mixed layer or the nocturnal stable layer.

3. The depth of the daytime mixed layer is represented by a diurnal cycle in which a daytime layer increases from a minimum depth at sunrise to a maximum depth in the afternoon. A nocturnal layer builds to a lower depth.

4. Depth of the boundary layer (mixed layer in daytime or nocturnal layer) for each hour determines which of two vertical dispersion regimes -mixed layer or above mixed layer -- will be applied to a given plume element. Those elements released within the depth of the layer expand according to the stability of the hour. Those released above the current depth of the layer expand as if the atmosphere were extremely stable. An exception to this method occurs when releases have expanded to the maximum depth of the mixed layer during the previous day; in this case their expansion continues according to a fixed function of travel time independent of stability or layer depth.

5. Depth of the mixed layer provides a vertical constraint for releases at heights within this layer. The depth of the nocturnal boundary layer does not serve as an analogous constraint. Carson (1973) supports this assumption by depicting the mixed-layer depth as a function that increases during the daytime, then loses its definition. This picture is in relative agreement with modeling results by Venkatram and Viskanta (1976) and with experiment results by Kaimal et al. (1976) who find that about one hour before sunset, the convective layer disintegrates rather 
abruptiy, although remnants of the capping inversion persist through the development of the nocturnal boundary layer.

6. At the present stage of model development, terrain effects are neglected. Diffusion equations are best explained by relating them to final concentration and deposition calculations where the average ground-level air concentrations over grid square $(i, j)$ are given by summing time-integrated concentrations [integrated over the time interval $(\Delta t)]$ and dividing by total assessment time $(T)$. Thus,

$$
x^{i j}=T^{-1} \quad \sum_{m(t)} \Delta x_{m}^{i j}(\Delta t ; t) .
$$

where $\Delta X_{m}^{i j}$ is the time-integrated, ground-level air concentration over $(i, j)$ for a pollutant carried by each plume element $(m)$ that is located over $(i, j)$ at time $(t)$.

At the end of each sampling interval $(\Delta t), \Delta x_{m}^{i j}$ is computed for the pollutant of each plume element that is on the grid by

$$
\Delta x_{m}^{i j}(\Delta t ; t)=\frac{Q_{m}(t) \Delta t}{A^{i j} Z_{m}},
$$

where

- $Q_{m}(t)$ is the mass carried by $m$ at $t$

- $A^{i j} \quad$ is the area of $(i, j)$

- $I_{m} \quad i 3$ the vertical dislribution factor for $m$ calculated by assuming Gaussian vertical distribution modified by reflection from the ground and from the top of the mixed layer.

If the vertical constraint height is $L$ and the effective stack height is $H, z_{m}^{-1}$ is: 


$$
\begin{gathered}
z_{m}^{-1}=\frac{\sqrt{2(\pi}}{\left(\sigma_{z}\right) m}\left\{e^{\frac{-1}{2}\left(\frac{H}{\sigma_{z}}\right)^{2}}+\sum_{k=1}^{\infty}\left[e^{\frac{-1}{2}\left(\frac{2 k L-H}{\sigma_{z}}\right)^{2}+}\right.\right. \\
e^{\left.\left.\frac{-1}{2}\left(\frac{2 k L+H}{\sigma_{z}}\right)^{2}\right]\right\}},
\end{gathered}
$$

where $\left(\sigma_{z}\right)_{m}$ is the vertical standard deviation for plume element $m$.

If $\sigma_{z}$ is small compared to $L$, the term represented by the entire summation over $k$ may be neglected. If $\sigma_{z}$ is approximately equal to or larger than $L$, the vertical distribution is approaching uniformity. Therefore, instead of calculating $Z^{-1}$ by a wasteful summation, $Z$ is set equal to $L$ :

$$
Z=L
$$

$L$ is the height of a reflection effective for transport at height $H$.

In the model, the depth in meters of the daytime mixed layer $\left(L_{d}\right)$ is given by:

$$
L_{d}\left(t_{h}\right)=200+1300 \sin \left[0.05 \pi\left(t_{h}-6\right)\right]
$$

when

$$
6 \leq t_{h} \leq 18
$$

and the depth of the nocturnal boundary layer $\left(B_{n}\right)$ is given by:

$$
B_{n}\left(t_{h}\right)=100+.300 \sin \left[0.05 \pi\left(t_{h}-18\right)\right]
$$


when

$$
18<t_{h}<30
$$

where $t_{h}$ is the hour of the day unless $t_{h}$ is greater than 24, in which case $t_{h}$ is specified as the hour of the day plus 24 to provide a continuous function.

These formulae were drawn up to approximate graphic results given by Carson (1973). They are advanced only for purposes of the calculations of the PNL model because the typical daytime inixed layer increases from $200 \mathrm{~m}$ at sunrise to $1500 \mathrm{~m}$ by late afternoon, and a nocturnal boundary layer develops to about $400 \mathrm{~m}$.

A11 plume elements not spread beyond the mixed-layer depth $(L)$ expand vertically as a function of travel distance. The increase of $\sigma_{z}$ is calculated using

$$
\sigma_{z}(x+\Delta x)=\sigma_{z}(x)+\Delta x \frac{\partial \sigma_{z}}{\partial x} \mid \begin{aligned}
& x \\
& S+1 / 2 \Delta x
\end{aligned}
$$

where $S$ indicates that the derivative differs according to the stability that is specified hourly in the mudel.

The formulae thus differentiated are those of Eimutis and Konicek (1972). If $H$ is greater than the mixed-layer depth ( $L_{d}$ or $B_{n}$ ), whichever applies at the time, the plume elements expand at the rate of $60 \%$ of that for Pasquill Stability 6 (Powell et al. 1979). This expansion rate results because mixing by mechanical turbulence is not effective above the mixed layer; therefore, the rate of vertical expansion is minimal.

All plume elements that have expanded vertically to fill the mixed layer at its maximum depth are released from the mixed-layer constraint at sunset 
when the boundary-layer structure collapses. These puffs expand as a function of time according to:

$$
\sigma_{z}\left(t+\Delta t ; L_{d m}\right)=\sigma_{z}\left(t ; L_{d m}\right)+\Delta t \sqrt{K_{z} / 2 t}
$$

where $K_{z}$ is the vertical diffusivity.

Heffter and Ferber (1975) recommend a value of $5 \mathrm{~m}^{2} \mathrm{~s}^{-1}$ for $\mathrm{K}_{\mathrm{z}}$. The plume elements not subject to the mixed-layer constraint after sunset include almost all those emitted during the previous $24 \mathrm{hr}$. Since these plumes all have the same vertical distribution at sunset, taken to be 1800 , they are a 1 assigned a common value of $t, 12 \mathrm{hr}$. If $L_{d m}$ is the maximum depth of the mixed layer at $t_{h}=18$ for each of these plume elements, then

$$
\sigma_{z}\left(12 \mathrm{hr} ; L_{d m}\right)=\left.\sigma_{z}\right|_{t_{h}=18}=\frac{L_{d m}}{\sqrt{\pi / 2}}
$$

A Gaussian plume calculation with $\sigma_{z}=L_{d m} \sqrt{2 / \pi}$ yields the same ground concentration as calculations for evenly distributed plumes over a layer of depth $L_{d m}$. Further plume expansion in time interval $(\Delta t)$ is given by:

$$
\sigma_{z}(12+\Delta t)=\frac{L_{d m}}{\sqrt{\pi / 2}}+\Delta t \sqrt{\frac{K_{z}}{2(12+\Delta t)}}
$$

The daytime plume expansion is illustrated in Figure 2. The plume at the bottom left is a low-level release, which expands at a rate corresponding to the stability of the hour to a height not greater than that of the mixed-layer depth. Farther to the right, an elevated plume is released above the mixed layer which expands very slowly so that it does not contribute to surface concentrations. Above both plumes, the depth of the boundary-layer is shown by $L_{d}$. At a later hour when $L_{d}$ rises above the stack, the second.plume will also expand according to the stability of the hour. Above $L_{d m}, \sigma_{z}$ of 


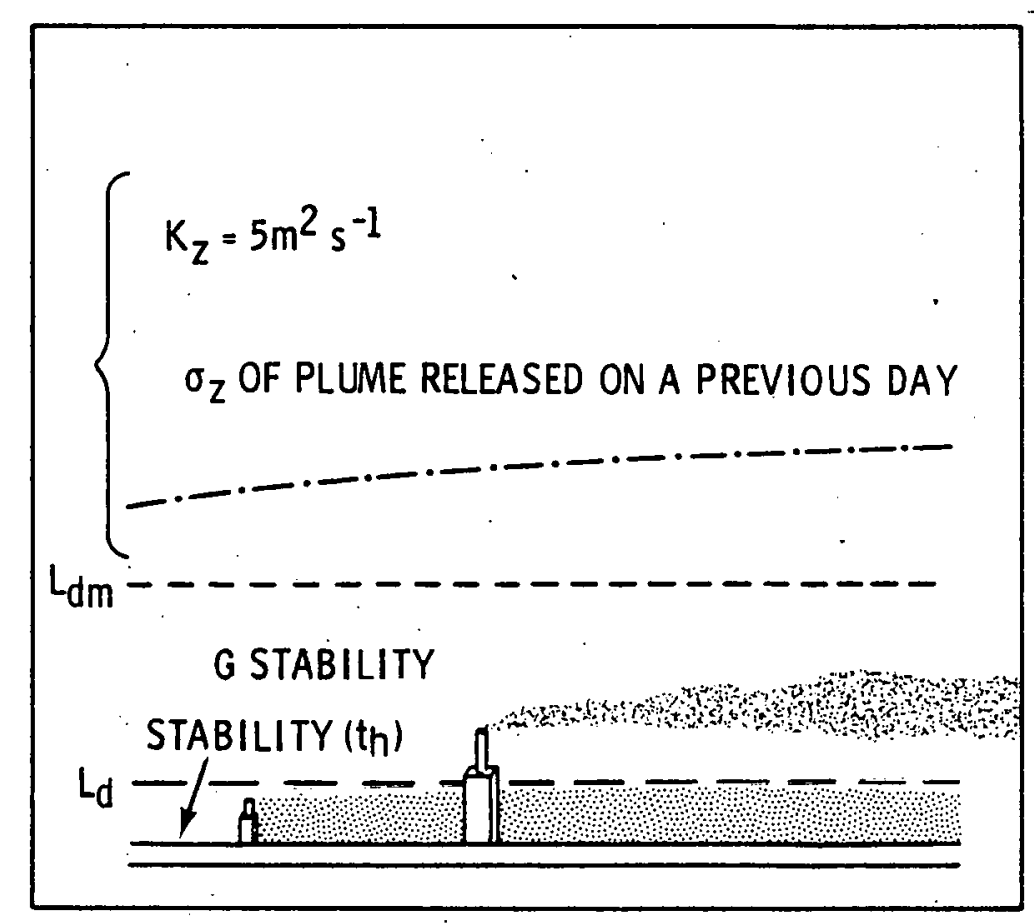

FIGURE 2. Daytime Illustration of Stability Definition and Vertical Constraints

a plume release on a previous day is shown. This plume expands at the rate given by Equation (8), an expansion rate that reflects the effects of convection averaged over a 24-hr period at the higher levels.

The hourly stability array used for the diurnal cycle generally allows for stable conditions at night, unstable conditions in the afternoon, and neutral transition hours. The portion of time allotted to each classification corresponds to an average climatology of stability over the United States based on the work of Doty, Wallace, and Holzworth (1976). During unstable hours in the afternoon, all plume elements quickly become evenly distributed throughout the mixed. layer. 


\section{REMOVAL MECHANISMS}

The removal of respirable particulates from the atmosphere by dry and wet deposition are calculated by a set or ordinary linear differential equations that are solved for each plume element. These equations assume that:

- Dry-removal rate is obtained by multiplying the deposition velocity by the vertical distribution factor $z^{-1}$.

- Wet-removal rate is a function of the local precipitation rate.

The following definitions are used in the equations:

- $Q(t)$ : Mass of respirable particulates in a plume element at time $t, \mu g$

- $D(t)$ : Mass deposited from a plume element up to time $t, \mu g$

- d: Coefficient of dry deposition, $\mathrm{hr}^{-1}$

- w: Coefficient of wet deposition, $\mathrm{hr}^{-1}$.

Given the above definitions,

$$
\begin{aligned}
& \frac{d Q}{d t}=-(d+w) Q, \\
& \frac{d D}{d t}=(d+w) Q,
\end{aligned}
$$

Solutions of these equations are expressed by the change of mass for each plume element $(m)$ over the advection time $(\Delta t)$ and by the mass to be deposited over grid unit $(i, j)$ from $m$ over the same time interval, usually one hour.

The calculated deposition is expressed in terms of mass $\mathrm{m}^{-2}$ month $^{-1}$. Thus, the monthly deposition ( $F$ ) applying to $i, j$ may be written as:

$$
F^{i j}=\gamma^{-1} T^{-1} \sum_{m(t)} \Delta F_{m}^{i j}(\Delta t ; t)=Y^{-1} T^{-1} \sum_{m(t)} \frac{D_{m}^{i j}(\Delta t ; t)}{A^{i j}}
$$


where $Y$ is one month in units of $T$ and $\Delta F_{m}^{i j}$ is the deposition of pollutant, mass per unit area, over time interval $(\Delta t)$ over grid square $i, j$ because of plume element $m$ at time $(t)$.

$D_{m}^{i j}(\Delta t ; t)$ is a more complete notation for the deposited mass, The $D_{m}^{i j}$ are divided into dry and wet deposition.

$$
D_{m}^{i j}=Q_{m} D_{m}^{i j}(\Delta t ; t)
$$

where $D_{\mathfrak{m}}^{i j}(\Delta t ; t)$ is given by:

$$
D_{m}^{i j}(\Delta t ; t)=1-\operatorname{EXP}\left\{\left[-\frac{\overline{V d}}{z_{m}(t)}-\lambda p^{i j}(t)^{n}\right] \dot{\Delta t}\right\}
$$

where

- $\overline{V d}$ is the deposition velocity.

- $Z_{m}(t)$ is the vertical distribution factor for $m$.

- $p^{i j}(t)$ is the precipitation rate at $t$ over $i, j$, and $\lambda$ and $n$ are precipitation scavenging parameters.

The model currently assumes that $\overline{\mathrm{Vd}}, \lambda$, and $n$ are constants.

Relating Equation (12) to Equation (15) yields:

$$
\begin{aligned}
& d=\overline{V d} / z_{m}(t), \\
& w=\lambda p^{i j}(t)^{n}
\end{aligned}
$$

A constant value for each of these parameters was selected even though they are all known to vary in space and time with changing physical conditions.

- The parameter values chosen for the model test case are: 


$$
\begin{aligned}
& \overline{V d}=0.23 \mathrm{~cm} \mathrm{~s}^{-1}, \\
& w=0.38 p^{i j}(t)^{.73} \mathrm{hr}^{-1},
\end{aligned}
$$

where $P^{i j}(t)$ is in $\mathrm{mm} \mathrm{hr} r^{-1}$.

The dry- and wet-removal parameters were selected to approximate the removal from the atmosphere of emitted particulates in the respirable size ranges of approximately 0.1 to $3.0 \mu \mathrm{m}$ dia. The dry deposition velocity of $0.23 \mathrm{~cm} \mathrm{sec}^{-1}$ is somewhat larger than the $0.1 \mathrm{~cm} \mathrm{sec}^{-1}$ of ten selected as a mean value for sulfate aerosols (Garland 1978), but is well within the range of measured values for fine particulates (Droppo and Doran 1979). The wet removal parameterization was derived by Scott and Dana (1979) (also Scott 1978) for sulfate aerosols, on the assumption that subcloud-sulfate aerosol acts as cloud-condensation nuclei and is removed by the accretion process. This parameterization was applied to emitted particulates in the respirable size range on assumption these also serve as cloud-condensation nuclei (Puesche1 1976; Parungo et al. 1978).

\section{PRECIPITATION AVERAGING}

In the assessments for this report, hourly precipitation is available for use. However, where a large number of sources are used or a large time period is involved, the computer cost becomes prohibitive. Therefore, a technique that allows the use of average precipitation was used. This technique uses the average precipitation rate that occurs during precipitation events. Precipitation is turned "on" for the average period of precipitation and "off" for the average period of no precipitation. For the entire assessment period for this report, a value of $3 \mathrm{hr}$ of precipitation out of every $120 \mathrm{hr}$ was chosen based on a rough average of values presented by Hemmi and Reiter (1978). 
THIS PAGE

WAS INTENTIONALLY

LEFT BLANK 


\section{GRID POINT ASSESSMENTS}

In general, grid-point assessments are usually carried out at source points. However, because of the large number of sources (238) at the centroids of the AQCRs and the expense of running the long-range transport model, an alternative approach was tried using fewer source points. This alternative approach was to run the assessments for sources at grid intersects on the advection grid. Then, after weighting these grid point assessments on the basis of the inverse square of the distance from the grid point to the source point at the centroid of an $A Q C R$, the weighted assessments were superimposed on the source and added together, forming an estimated assessment at the source point.

The assessment grid points are shown in Figure 1 . Since there are 86 points, this means a factor of $\sim 3$ fewer assessments to run. In general, the regular spacing of the NMC grid is used. There are four exceptions--one point is used in Maine, two points in Florida, and one point in California. Two points (Maine and California) are located at the half-grid spacing both in $X$ and $Y$, whereas two points in Florida are located at the half-grid only in $X$. The reason why these additional grid points were chosen is that precipitation effects for the local region would not have shown up on the advection grid spacing. If points on the regular grid had been chosen, the points would have been over water where no precipitation would be included. Although the two points in the upper left-hand corner of Figure 1 are over water, these points are close enough to shore to be covered by the hourly precipitation grid area and thereby precipitation effects can be seen.

\section{TEST CASES}

At the present time, the method used for testing whether more grid-point assessments are needed has been through a direct comparison of an assessment at a source point versus the weighted grid-point assessment from the surrounding four grid points.

Two test cases for comparison have been made using meteorological data for July 1974. The first test is for a single source located in the Four 
Corners region. Figure 3 shows the source location and the four surrounding NMC grid points used to interpolate the grid-point assessments to the source. The air concentration from an assessment run at the source point is shown in Figure 4. The air concentrations from the estimated assessment from the four. NMC grid points is shown in Figure 5 . The basic pattern in Figure 5 is quite similar to the pattern in Figure 4 although differences can be seen. When the centerline values were compared, ratios of these values generally ran between 0.5 to 2.0. Large differences in Wyoming can be seen between figures. In the single-source assessment, a large low appears in Wyoming. In the four NMC grid-point estimated assessments, there are low values in Wyoming although these values are a factor of 10 higher than the source values. In southcentral Montana, factors as high as 50 are seen between the two patterns. Greater differences occur in the deposition patterns shown in Figures 6 and 7. However, the overall mass balances for the Four Corners single-source and grid-point comparison are essentially the same (see Table 1).

The second test was for multiple sources in the western United States for a Regional Issues Identification Assessment (RIIA) utility 1985 particulate analysis. This test focused on the effects of using average precipitation instead of hourly precipitation for a multisource assessment. Work performed by Davis using a single source (1979) has shown that the mass balance is approximately the same when using the average precipitation and turning it "on" and "off" based on the average dry time and the average wet time. Since work was not performed previously using multiple sources, a run was made using

TABLE 1. Mass Balances for Single Source Four Corners Test (July 1974)

Final Particulate Location

Airborne--remaining over grid

Total deposited

Wet deposition on ly

Transported off grid

Dropped after remaining airborne for $200 \mathrm{hr}$
Percent of Particulate Emissions

\begin{tabular}{ll}
\hline Four Corners & Four Corners \\
Single Source & Grid Estimate \\
\hline
\end{tabular}

$$
8.31
$$

7.88

82.79

82.91

53.92

54.10

5.49

6.13

3.40

3.09 


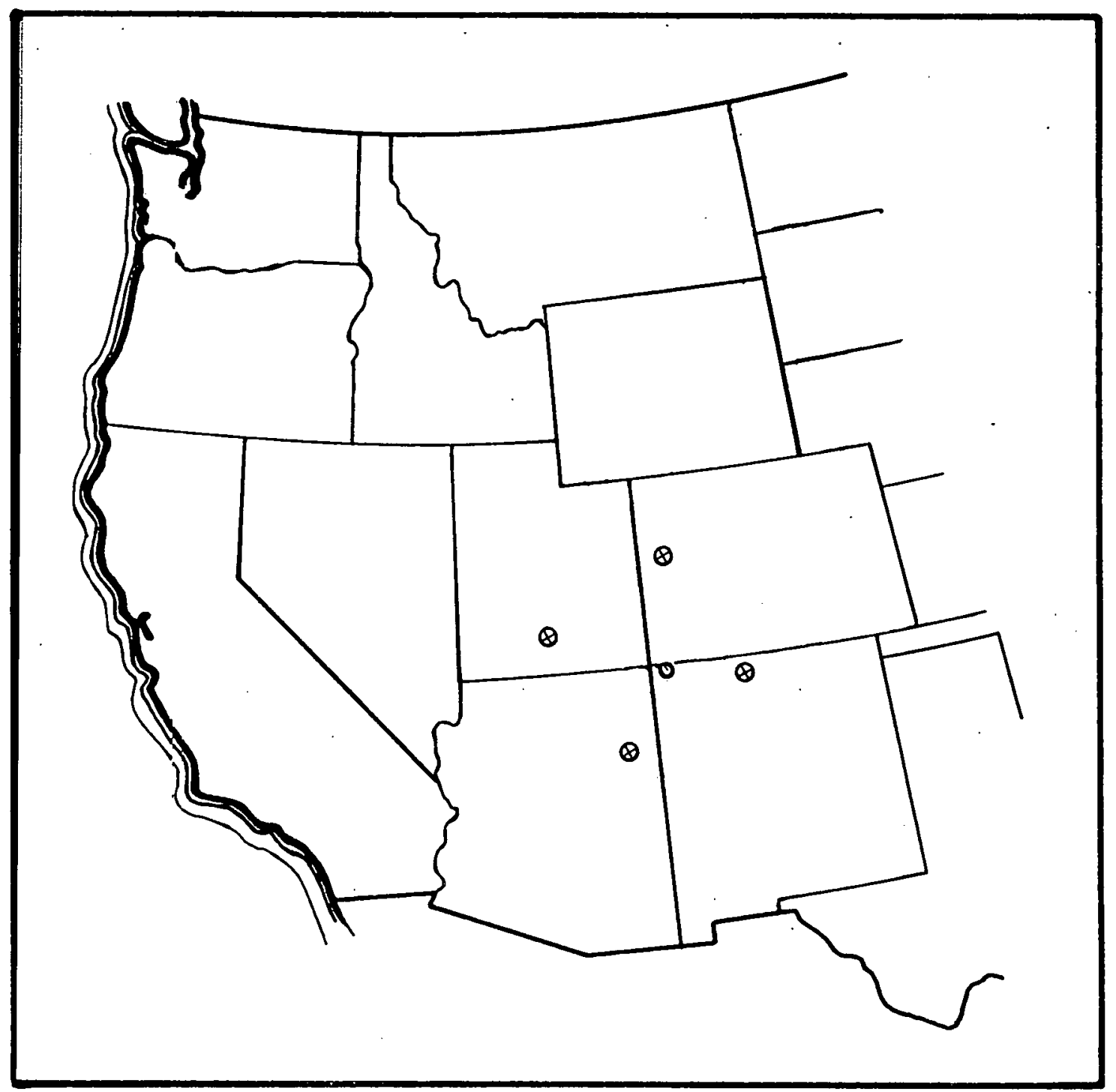

FIGURE 3. Source Location in Four Corners Region and Four Surrounding Grid-Point Source Locations 


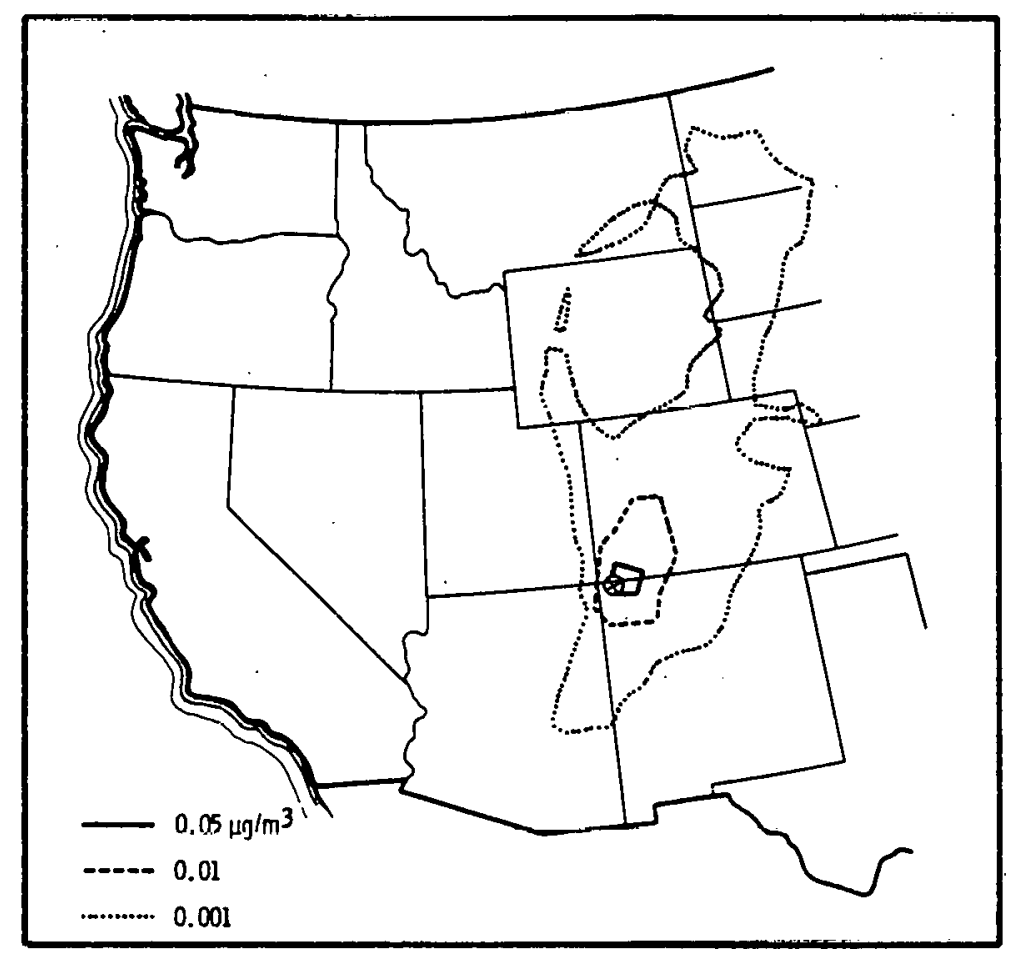

FIGURE 4. Average Particulate Air Concentrations for Single Source in Four Corners Region, $\mu \mathrm{g} \mathrm{m} \mathrm{m}^{-3}$ (July 1974)

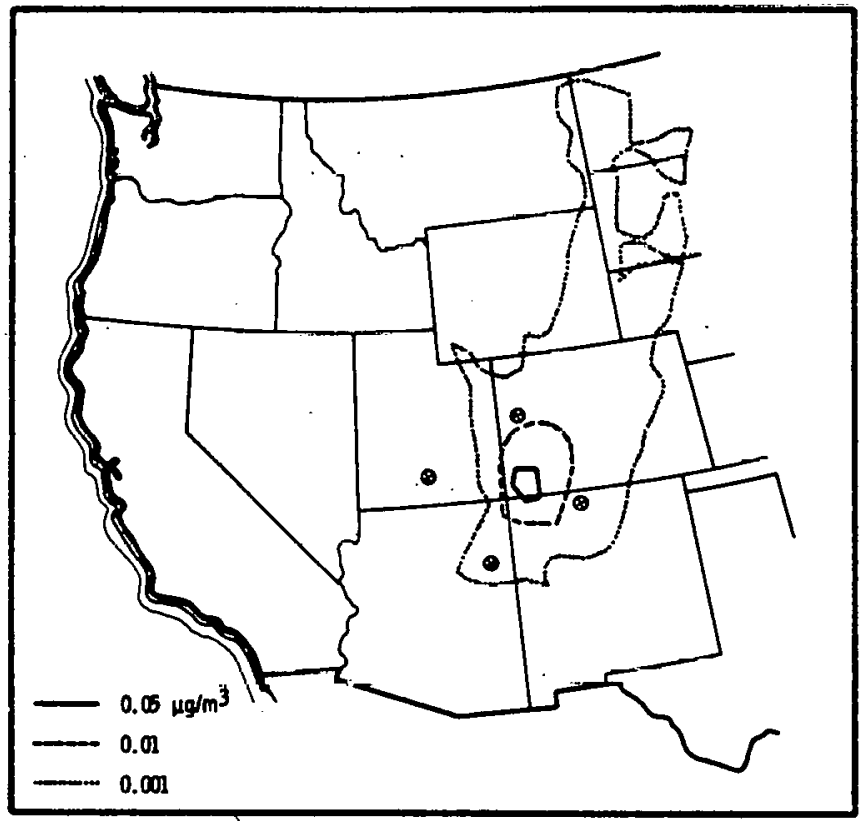

FIGURE 5. Average Particulate Air Concentrations for Single Source in Four Corners Region Interpolated from Assessments for Sources at Four Surrounding Grid Points, $\mu \mathrm{g} \mathrm{m}^{-3}$ (July 1974) 


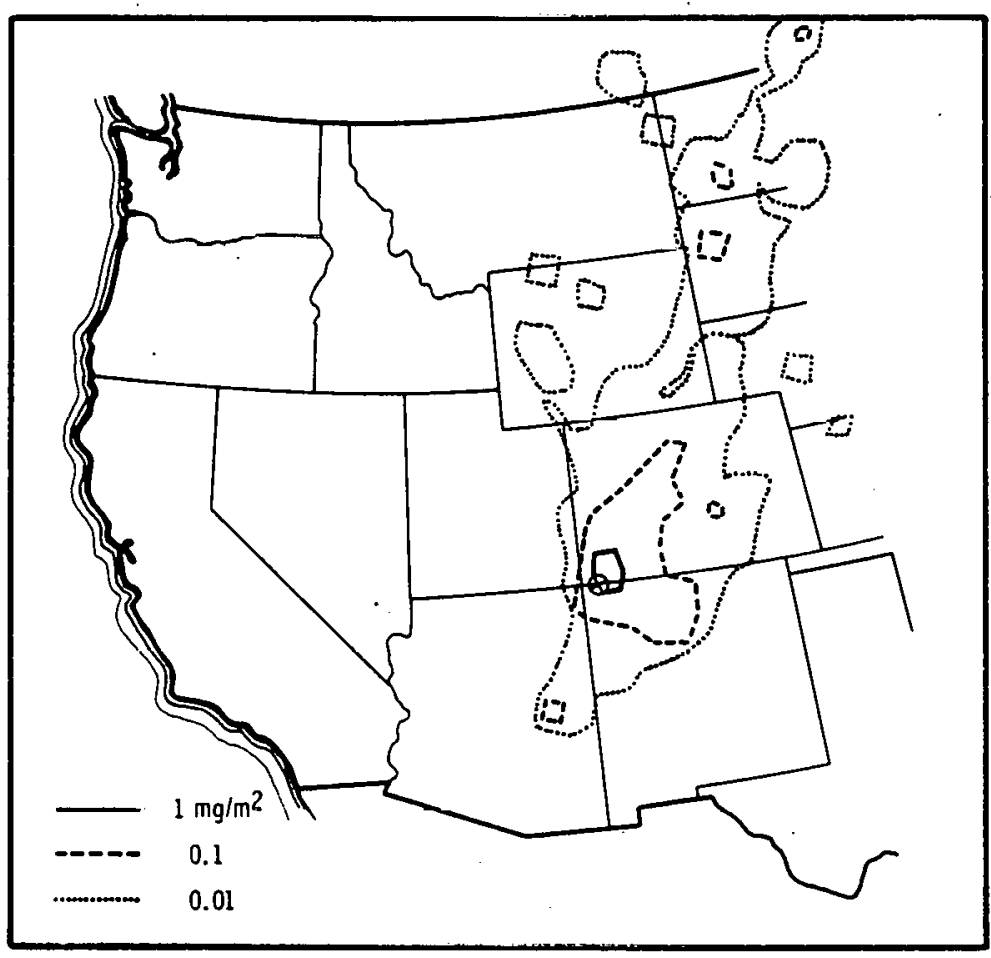

FIGURE 6. Average Particulate Depositions for Single Source in Four Corners Region, mg m-2 (July 1974)

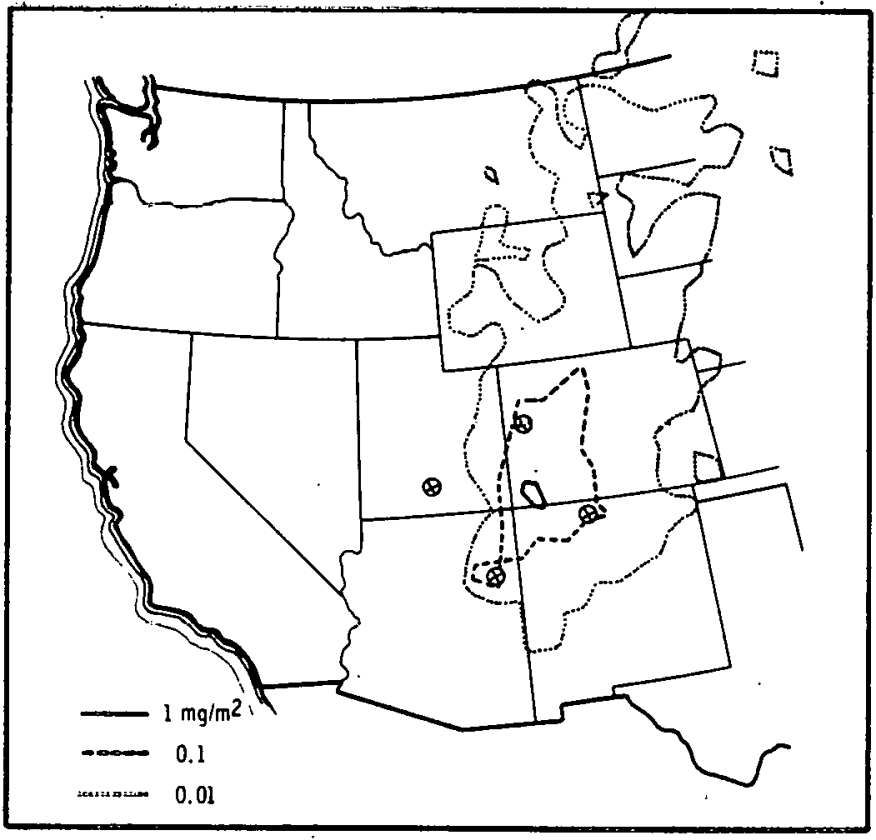

FIGURE 7. Average Particulate Depositions for Single Source in Four Corners Region Interpolated from Assessments for Sources at Four Surrounding Grid Points, $\mathrm{mg} \mathrm{m}^{-2}$ (July 1974) 
the multiple sources used in the RIIA utility 1985 particulate assessment for July 1974 (see Figure 8 ). The results using the interpolative four-point technique for an estimated assessment is shown in Figure 9 for hourly precipitation and in Figure 10 for average precipitation. As can be seen in the comparisons for the air concentrations, the patterns are virtually the same.

The biggest differences in the assessments are in the deposition patterns as shown in Figures 11 and 12 for the hourly precipitation and Figure 13 for the average precipitation. The reason for this difference is that when precipitation is generally infrequent, six to seven events per month for this study, the deposition pattern is heavily influenced as to when and where precipitation occurs. Over longer time periods, this effect would be expected to average out.

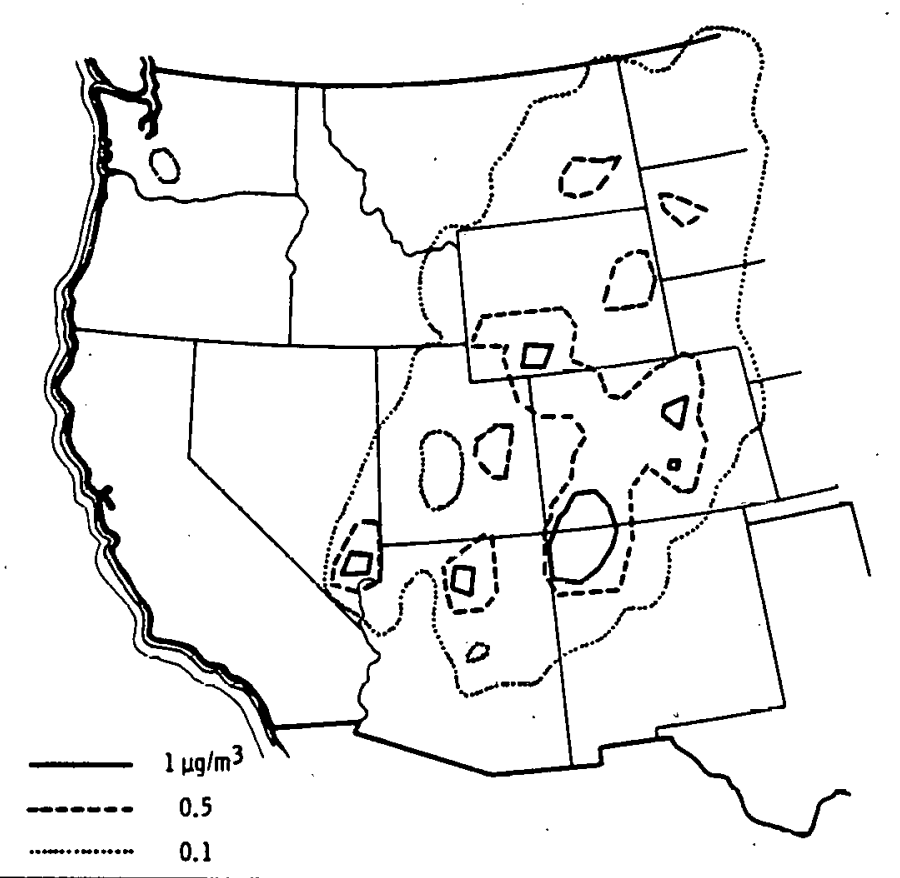

FIGURE 8. Average Particulate Air Concentrations for an RIIA Utility 1985 Scenario Computed Using Hourly Precipitation for Wet Removal, $\mu \mathrm{g} \mathrm{m}^{-3}$ (July 1974) 


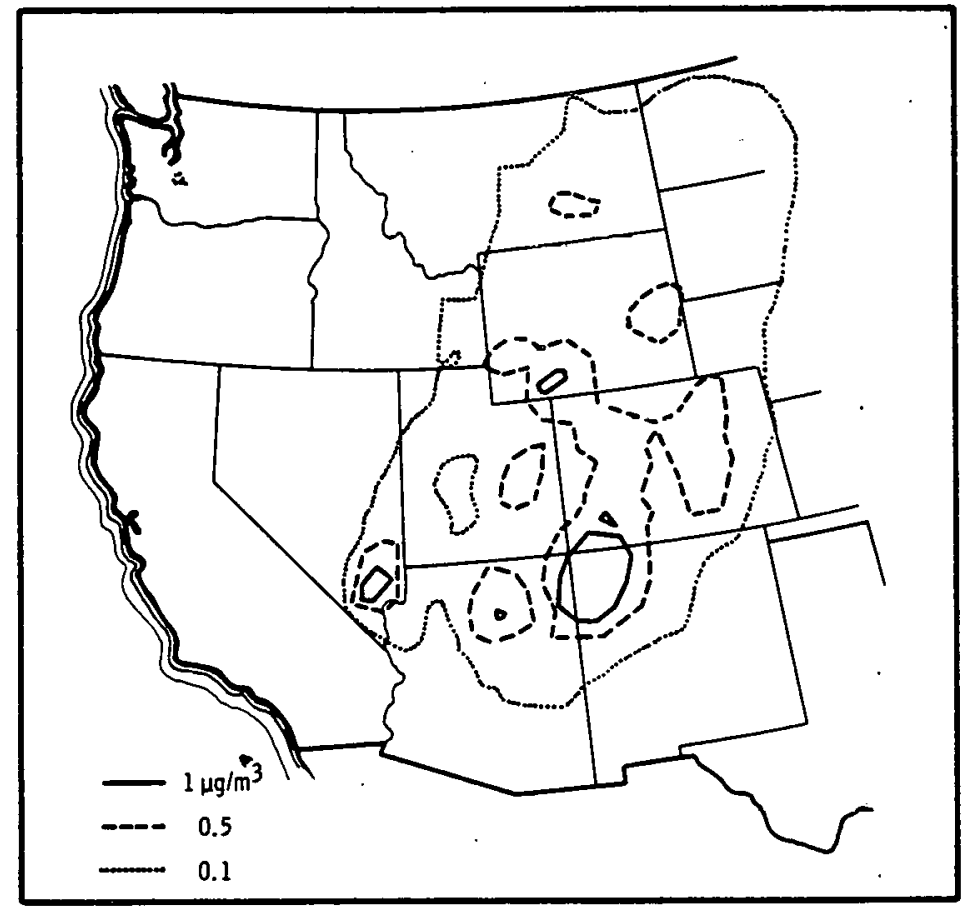

FIGURE 9. Average Particulate Air Concentrations for an RIIA Utility 1985 Scenario Interpolated from Grid-Point Assessments Using Hourly Precipitation. for Wet Removal, $\mu \mathrm{g} \mathrm{m}^{-3}$ (July 1974)

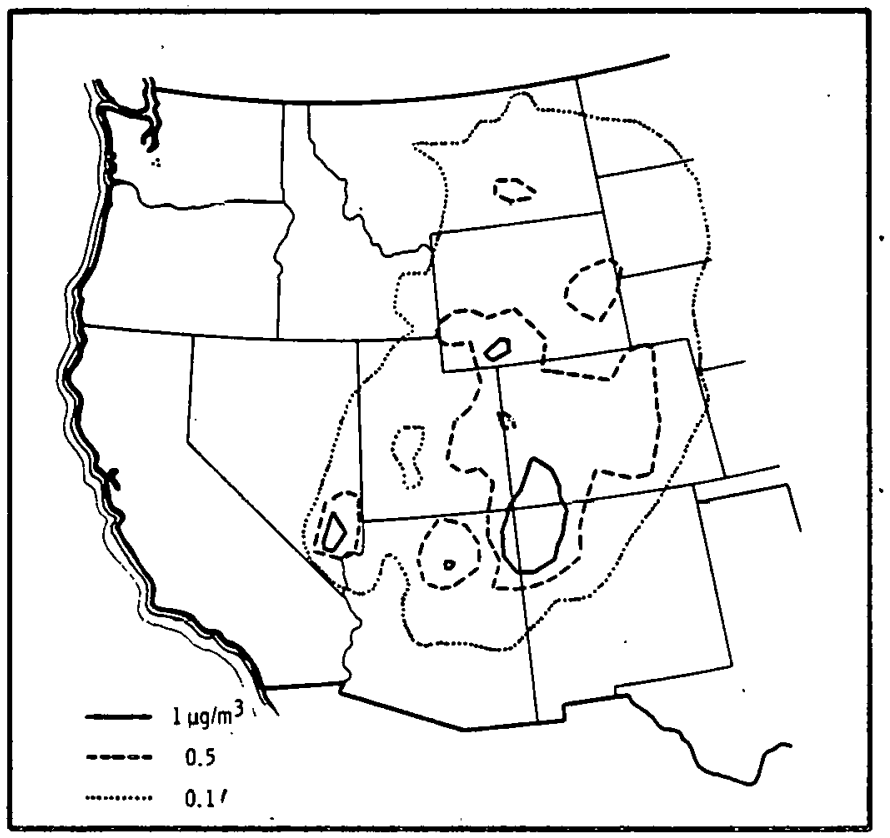

FIGURE 10. Average Particulate Air Concentrations for a RIIA Utility 1985 Scenario Interpolated from Grid-Point Assessments Using TimeAveraged Precipitation for Wet Removal, $\mu \mathrm{g} \mathrm{m}^{-3}$ (July 1974) 


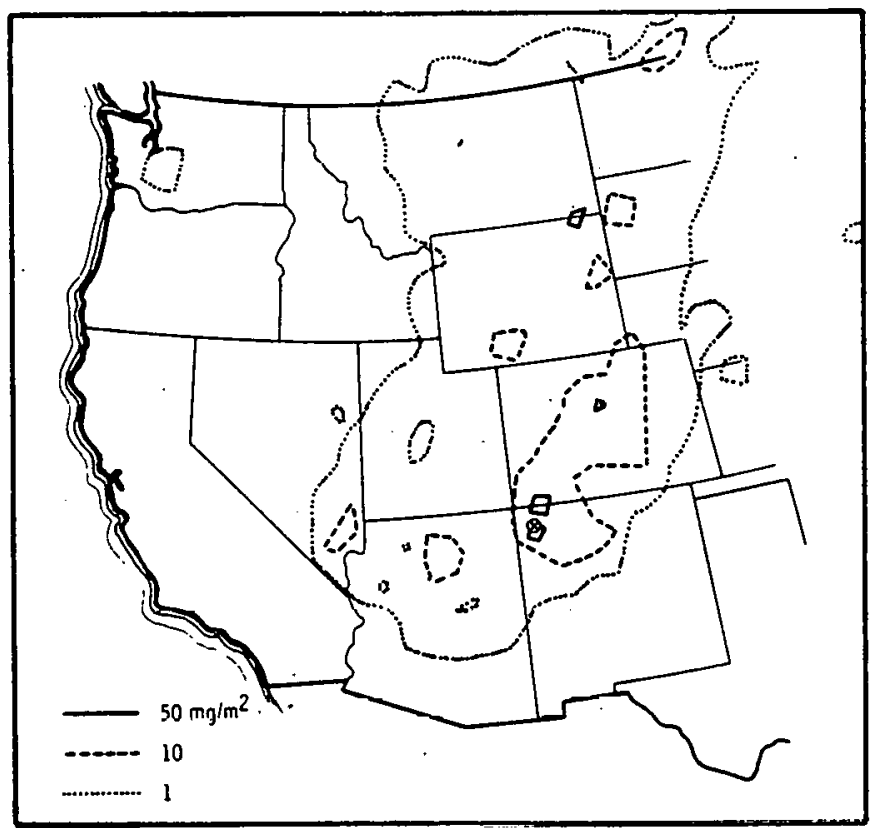

FIGURE 11. Average Particulate Deposition for an RIIA Utility 1985 Scenario, Computed Using Hourly Precipitation for Wet Remova 1, mg m-2 (July 1974)

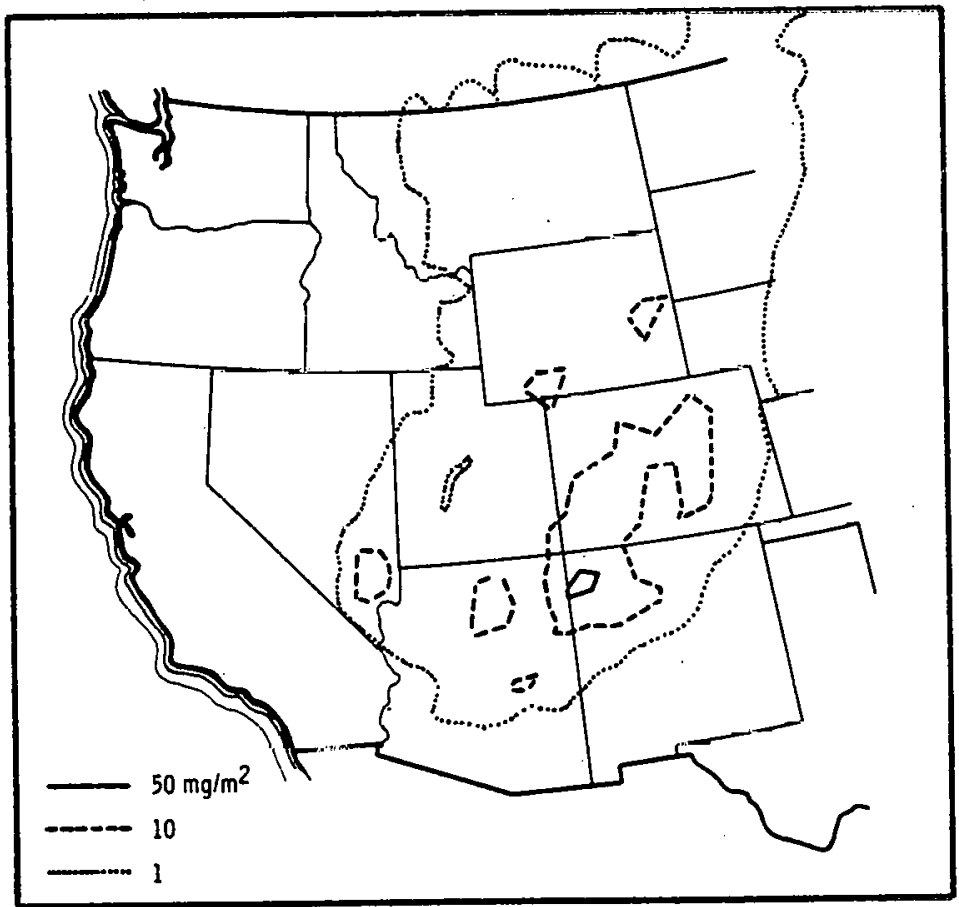

FIGURE 12. Average Particulate Deposition for an RIIA Utility 1985 Scenario Interpolated from Grid-Point Assessments Using Hourly Precipitation for Wet Removal, $\mathrm{mg} \mathrm{m}^{-2}$ (July 1974) 


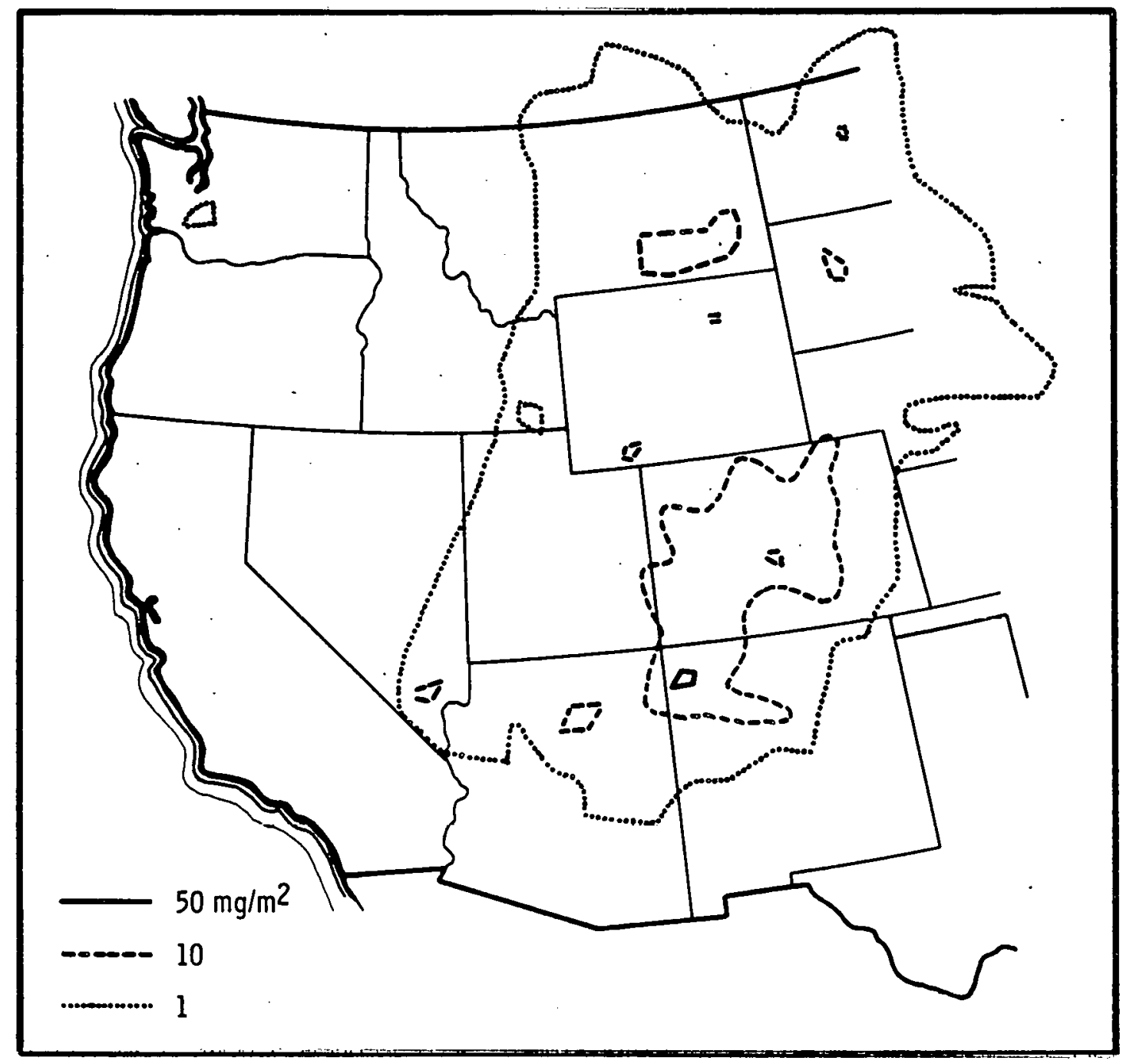

FIGURE 13. Average Particulate Deposition for an RIIA Utility 1985 Scenario Interpolated from Grid Point Assessments Using Time-Averaged Precipitation for Wet Removal, $\mathrm{mg} \mathrm{m}^{-2}$ (July 1974) 
THIS PAGE

WAS INTENTIONALLY LEFT BLANK 


\section{THE AQCR ASSESSMENTS}

As a result of favorable comparisons shown in the test cases (in Section IV), a decision was made to use the grid-point assessment technique for an assessment of monthly, average respirable particulate fields emitted from all the AQCRs contained in the 48 contiquous states. The basic model parameters, as well as times over which the model was run for these assessments, is shown in Table 2. By using the grid-point technique, four months of assessments at 86 grid points were made instead of, because of cost, only one month of assessments at 238 source points.

The 86 grid points were used to estimate assessments for a source at the centroid of each AQCR. After the assessments were made, the effect of one $A Q C R$ on another $A Q C R$ remained to be evaluated. 
TABLE 2. Long-Range Transport Model Parameters for Generation of Respirable Particulate AQCR-to-AQCR Matrices

\section{Long-Range Transport Mode1 Parameters}

Time periods for meteorological data

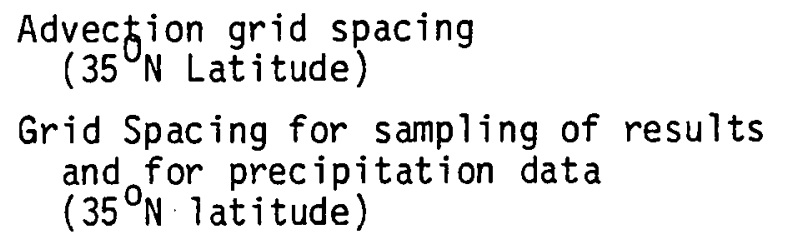

Source emission rate

Source locations (86)

Effective source stack height

Maximum daytime mixing height

Minimum daytime mxing height

Maximum nighttime stable layer height

Minimum nighttime stable layer height

Stability

Dry deposition velocity

Wet removal

Puff release rate from source, advection time step, and sampling rate of puffs for results

Maximum number of hours a puff trajectory will be continued if it stays on grid

Averaging period for air concentration fields of respirable particulates

Units of air concentrations of respirable particulates
1-31 January 1974

1-30 April 1974

1-31 JuTy 1974

1-31 October 1974

$321 \mathrm{~km}$

$32 \mathrm{~km}$

$1.0 \mathrm{kiloton} / \mathrm{yr}$

Advection grid intersections

for interpolation to centroids of $A Q C R$

$200 \mathrm{~m}$

$1500 \mathrm{~m}$

$200 \mathrm{~m}$

$400 \mathrm{~m}$

$100 \mathrm{~m}$

Varied through the diurnal cycle $0.23 \mathrm{~cm} / \mathrm{sec}$

$.38 \mathrm{P} .73 / \mathrm{hr}$, where $\mathrm{P}=$ rainfall rate in $\mathrm{mm} / \mathrm{hr}$

1 per $\mathrm{hr}$

$200 \mathrm{hr}$

1 mo

$\mu g / m^{3}$ 


\section{GENERATION OF AQCR-TO-AQCR MATRICES}

\section{POPULATION-WEIGHTED AVERAGING}

To accomplish the population-weighted averaging over receptor AQCRs of the monthly, average respirable particulate fields from emitter AQCRs, two files on the BNL computer system were integrated to produce a file containing the $i$ and $j$ coordinates of the grid boxes in the PNL 32-km grid system that lie wholly or partially within each AQCR. Associated with each of the grid boxes contributing to a given $A Q C R$ is a population-weighting factor equal to. the population in the grid box residing within that AQCR divided by the total population residing within that AQCR.

One of the BNL files contains for each of the grid boxes in the BNL 32-km grid system within the continental United States a list of counties by Federal Information Processing Standards (FIPS) County Code that lie wholly or partially within the grid box. For each grid box, the population residing within that box is given for the years 1970, 1975, 1980, and 1990, as well as the fractional population contribution for each county for each of those years. A second BNL file contains a list of counties within the continental United States by FIPS County Code, along with state abbreviation and county name. Each county is assigned an AQCR number running from 1 to 243, with numbers 8 through 11 and 60 presently unassigned to AQCRs. The few counties in the United States that span two AQCRs were assigned in each case only to the one. AQCR that contains the larger portion of the county.

By using the county-level information from both BNL files and taking into account the slight differences in origin and dimensions between the. PNL and BNL grid systems, it was possible to develop an assignment of grid boxes in the PNL grid to the pseudo-AQCR and a population weighting factor for each grid-box assignment. The sum of the population weighting factors over the grid boxes assigned to each pseudo-AQCR equals unity. The BNL populations projections for the year 1985 form the basis for the initial population weighting for the PNL grid. 
To calculate the population-weighted average over a receptor AQCR of the monthly, average respirable particulate field from an emitter $A Q C R$, the respirable particulate concentration at every grid box assigned to the receptor AQCR is multiplied by the population weighting factor. The resulting product is summed over the grid boxes assigned to the receptor AQCR to compute a population-weighted average over the receptor AQCR. This procedure is repeated for every combination of emitter and receptor AQCRs to develop an interregional, long-range transport matrix for respirable particulates.

\section{RESULTS}

Four monthly average matrices were produced using meteorological data for the months of January, Apri1, July, and October, 1974. There can be considerable variation in the matrix elements from one month to another as presented in Table 3, where the monthly variations are shown for some representive AQCRs. Missing data in Table 3 means that there was no trajectory from the source at the centroid of the emitter $A Q C R$ to any of the grid cells that contribute to the receptor $A Q C R$ during that month. Very small matrix elements, such as for receptor AQCR No. 14 and emitter AQCR No. 65 in October 1974, arise when there were not enough trajectories from the emitter AQCR to the receptor AQCR for the monthly average concentration over the receptor AQCR to be a realistic number. In these cases, as in the cases of missing data, the monthly matrix element should be considered to be zero.

It will be seen in Table 3 that although there are some month-to-month variations in the diagonal elements, these diagonal elements for the four months can be averaged.together to produce a reasonably representative average matrix element. When the receptor $A Q C R$ is at some distance from the emitter $A Q C R$, considerably more monthly variations are seen in the matrix elements, with differences of several orders of magnitude between monthly values sometimes the case. In these cases, four months of meteorological data may not be enough to obtain an average value that is reasonably representative of a climatological average. 
TABLE 3. Monthly Variations in Long-Range Transport AQCR-to-AQCR Matrix Elements (a) for Respirable Particulates as Calculated Using Meteorological Data from Four Months in 1974

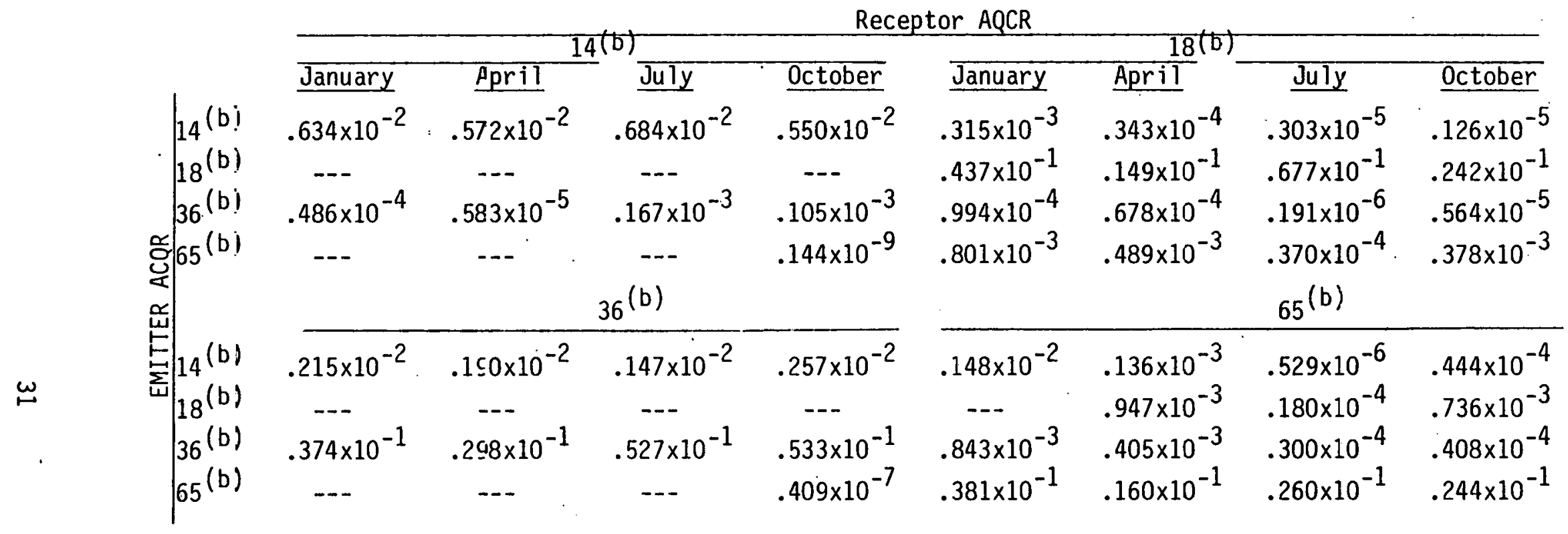

(a) Monthly average over receptor AQCR of respirable particulate air concentrations in micrograms per cubic meter, resu'ting from 1.0 kiloton per year emission from a source at centroid of emi tter AQCR.

(b) Counties included in AQCR:

- 14: AZ Apache, AZ Conconino, AZ Navajo, AZ Yavapai, CO Archuleta, Co Dolores, Co La Plata,

CO Montezuma, CO San Juan, NM McKinley, NM San Juan, UT Emery, UT Garfield, UT Grand,

UT Iron, UT Kane, UT San Juan, UT Washington, UT Wayne.

- 18: AR Crittenden, MŚ De Soto, TN Shelby

- 36: CO Adams, CO Arapahoe, CO Boulder, CO Clear Creek, CO Denver, Co Douglas, CO Gilpin,

CO Jefferson

- 65: IL Fulton, IL Hancock, IL Hendersen, IL Knox, IL McDonough, IL Mason, IL Peoria, IL Tazewell, IL Warren, IL Woodford, IA Des Moines, IA Lee. 
THIS PAGE

WAS INTENTIONALLY

LEFT BLANK 


\section{REFERENCES}

Bolin, B. and C. Persson. 1975. "Regional Dispersion and Deposition of Atmospheric Pollutants with Particular Application to Sulfur Pollution over Western Europe." Tellus XXVII. 3:281-310.

Carson, D. J. 1973. "The Development of' a Dry Inversion-Capped Convectively Unstable Boundary Layer." Quart. J. R. Met. Soc. 99:450-467.

Davis, W. E. 1979. "The Effect of Using Time Averaged Precipitation for the Estimation of Wet Deposition in a Regional Scale Model." Fourth Symposium on Turbulence, Diffusion, and Air Pollution. Reno, NV, January 15-18, 1979.

Davis, W. E. 1979. "Comparison of the Results of an Eight Layer Regional Model Versus a Single Layer Regional Model for a Short Term Assessment." Presented at the World Meteorological Organization Symposium on Long-Range Transport of Pollutants, Sophia, Bulgaria.

Doty, S. R., B. L. Wallace and G. C. Holzworth. 1976. A Climatological Analysis of Pasquill Stability Categories Based on "STAR" Summaries. Environmental Sciences Research Laboratory, Environmental Protection Agency, Research Triangle Park, NC.

Droppo, J. G: and J. C. Doran. 1979. "Dry Deposition of Air Pollutants." In the Proceedings of the Institute of Environmental Sciences, April 29-May 2, 1979 , Seatt le, WA.

Eimutis, E. C. and M. G. Konicek. 1972. "Derivations of Continuous Functions for the Lateral and Vertical Atmospheric Dispersion Coefficients." Atmos. Envir. 6: $859-863$.

Garland, J. A. 1978. "Dry and Wet Removal of Sulphur from the Atmosphere." Atmos. Envir. 12:349-362.

Heffter, J. L. and G. J. Ferber. 1975. A Regional-Continental Scale ransport, Diffusion, and Deposition Model - Park II: Diffusion-Deposition Models. NOAA Technical Memorandum ERL ARL-50, Air Resources Laboratories, Silver Spring, MD.

Henmi, T. and E. R. Reiter. 1978. "Regional Residence Time of Sulfur Dioxide Over the Eastern United States." Atmos. Envir. 12:1489-1495.

Kaimal, J. C., et al. 1976. "Turbulence Structure in Convective Boundary Layer." J. of the Atm. Sci. 33:2152-2169.

Parungu, F., E. Ackerman, H. Proulx and R. Pucsche 1. 1978. "Nucleation Properties of Fly Ash in a Coal-Fired Power-Plant Plume." Atmos. Envir. 12:929-935. 
Powe 11, D. C., D. J. McNaughton, L. L. Wendell and R. L. Drake. 1979. A Variable Trajectory Model for Regional Assessments of Air Pollution from Sulfur Compounds. PNL-2734, Pacific Northwest Laboratory, Richland, WA.

Powel1, D. C., H. L. Wegley and T. D. Fox. 1979. MESODIFF-II: A Variable Trajectory Plume Segment Model to Assess Ground-Level Air Concentrations and Deposition of Routine Effluent Releases from Nuclear Power Facilities. PNL-2419, U.S. Nuc Tear Regulatory. Commission, 1979.

Prahm, L. R. and 0. Christensen. 1977. "Long-Range Transmission of Pollutants Simulated by the 2-D Pseudospectral Dispersion Mode1." J. A. M. 16:696-910.

Pueschel, R. 1976. "Aerosol Formation During Coal Combustion." Geophys. Res. Lett. 3: $351-653$.

Renne, D. S., W. J. Eadie and D. L. Elliott. 1978. "Air Quality Impacts." In: The Impact of Increased Coal Consumption in the Pacific Northwest. BNWL-RAP-21, Pac if ic Northwest Laboratory, Richland, WA.

Sandusky, W. F., W. J. Eadie and D. R. Orewes. 1979. Long-Range Transport of Sulfur in the Western United States. PNL-RAP-26, Pacific Northwest Laboratory, Richland, WA.

Scott, B. C. 1978. "Parameterization of Sulfate Removal by Precipitation." J. A. M. 17:1375-1389.

Scott, B. C. and M. T. Dana. 1979. Deviation of Wet Removal Rates for $\mathrm{SO}_{2}$ Gas and $\mathrm{SO}_{4}$ Aerosol. PNL-2850, PT3, Pacific Northwest Laboratory, Richland, WA.

Tennekes, H. 1974. "The Atmospheric Boundary Layer." Physics Today. 52-63.

Venkatram, A., and R. Viskanta. 1976. Radiative Effects of Pollutants on the Planetary Boundary Layer. U.S. Environmental Protection Agency Report EPA-600/4-76-039, Office of Research and Development, Research Triangle Park, NC.

Wende11, L. L. 1972. "Mesoscale Wind Fields and Transport Estimates Determined from a Network of Wind Towers." Mon. Wea. Rev. 100:565-578.

Wende11, L. L., D. C. Powell and R. L. Drake. 1976. "A Regional Scale Model for Computing Deposition and Ground Level Air Concentration of $\mathrm{SO}_{2}$ and $\mathrm{SO}_{4}$ from Elevated and Ground Sources." Preprints from the Third Symposium on Atmospheric Turbulence, Diffusion and Air Quality, Amer. Metenr. Soc., Raleigh, NC. 


\section{DISTRIBUTION}

No. of

Copies

\section{OFFSITE}

W. W. Burr

DOE Office of Health and

Environmenta 1 Research

Washington, DC 20545

E. S. Burton

DOE Resource Applications and Evaluation

Washington, DC 20545

C. E. Carter

DOE Office of Environmental

Research

Washington, DC 20545

Paul Cho

DOE Office of Technology

Impacts

Washington, DC 20545

A. A. Churm

DOE Chicago Patent Group

9800 South Cass Avenue

Argonne, IL 60439

Mrs. Ruth Clusen

DOE Assistant Secretary

for Environment

Washington, DC 20545

J. A. Coleman

DOE Office of Technology Impacts

Washington, DC 20545

C. W. Edington

DOE Office of Health and Environmental Research .Washington, DC 20545
No. of

Copies

Helen McCammon

DOE Office of Health and Environmental Research Washington, DC 20545

A. J. Goldberg

DOE Office of Technology Impacts

Washington, DC 20545

Dr. Joan Hock

DOE Office of Technology Impacts

Washington, DC 20545

P. W. House

DOE Office of Technology Impacts

Washington, DC 20545

A. B. Joseph

DOE Office of Nuclear Regulatory Research Washington, DC 20555

F. G. Lowman

DOE Office of Nuclear Regulatory Research Washington, DC 20555

J. Maher DOE Office of Technology Impacts

Washington, DC . 20545

S. P. Mathur

DOE Office of Technology Impacts

Washington, DC 20545 
No. of

Copies

W. J. McCool

DOE Office of Environmental

Compliance and Overview

Washington, DC 20545

D. M. Monti

DOE Office of Technology

Impacts

Washington, DC 20545.

W. E. Mott

DOE Office of Environmental

Compliance and Overview

Washington, DC 20545

M. Reilly

DOE Division of Fossil Energy

Washington, DC 20545

G. J. Rotariu

DOE Office of Technology

Impacts

Washington, DC 20545

R. D. Shull

DOE Office of Technology

Impacts

Washington, DC 20545

B. W. Wachholz

DOE Office of Technology Impacts

Washington, DC 20545

E. R. Williams

DOE Office of Technology Impacts

Washington, DC 20545

R. W. Wood

DOE Office of Environmental

Research

Washington, DC 20545
No. of

Copies

27 DOE Technical Information Center

S. Ballou

Argonne National Laboratory

9700 South Cass Avenue

Argonne, IL 60439

L. J. Hoover

Argonne National Laboratory

9700 South Cass Avenue

Argonne, IL 60439

P. M. Meier

Building 475

Brookhaven National Laboratory

Upton, NY 11973

W. E. Siri

University of California

Lawrence Berkeley Laboratory

Berkeley, CA 94720

D. Layton

University of California

Lawrence Livermore Laboratory

P. 0. Box 808

Livermore, CA 94550

R. K. Lohrding

Los Alamos Scientific Laboratory

P. 0. Box 1.663

University of California

Los Alamos, NM 87545

R. M. Davis

Oak Ridge National

Laboratory

P. 0. Box $X$

Oak Ridge, TN 37830 
No. of

Copies

W. Fulkerson

Oak Ridge Nationa 1

Laboratory

P. 0. Box X

Oak Ridge, TN 37830

\section{ALASKA}

J. Halterman

State Clearinghouse

Division of P.olicy Development and Planning

Office of the Governor

Pouch AD

Juneau, AK 99801

J. Lowe 11 Jensen

Public Utilities Commission

Mackay Building

338 Denali Street

Anchorage, AK 99501

G. Martin

Department of Natural

Resources

State Office Building

Pouch $M$

Juneau, AK 99801

C. Quinlan

Department of Commerce and Economic Development .

Mackay Building

338 Denali Street

Anchorage, AK 99501

Col. G. R. Robertson

District Engineer

Alaska District

Corps of Engineers

P. 0. Box 7002

Anchorage, AK. 99501
No. of

Copies

CALIFORNIA

R. Doel1

U. S. Geological Survey 354 Middlefield Road

Men lo Park, CA 94025

W. Esselman

Electric Power Research Institute

P. 0. Box 10412

Palo Alto, CA 94304

L. Henning

Electric Power Research Institute

P. 0. Box 10412

Palo Alto, CA 94304

E. Neblet

DOE Federal Energy Regulatory Commission

U.S. Custom House

San Francisco, CA. 94111

R. Uhler

Electric Power Research Inst itute

P. 0. Box 10412

Palo Alto, CA 94304

$\underline{\text { IDAHO }}$

D. Guss

Bureau of State Planning and Community Affairs

State House

Boise, ID 83720

L. K. Hall

Idaho Energy Office

State House

Boise, ID 83720 
No. of

Copies

M. Neville

Idaho Legislative Council

State House

Boise, ID 83702

K. D. Smith

Public Utilities

Commission

472 W. Washington Street

Boise, ID 83720

R. J. Vissia

Bureau of Reclamation

Federal Building

550 West Fort Street

Boise, ID 83724

R. N. Wise

Bureau of State Planning and Community Affairs

State House

Boise, ID 83720

\section{MONTANA}

J. Binanado

Bureau of Land Management

P. 0. Box 30157

Billings, MT 59107

$\underline{\mathrm{OHIO}}$

Ann Rudolph

Battelle Memorial Institute

505 King Avenue

Columbus, $\mathrm{OH} 43201$

\section{OREGON}

Col. H. L. Arnold, Jr.

Distriet Fngineer

Portland District

Corps of Engineers

P. 0. Box 2946

Portland, OR 97208
No. of

Copies

R. A. Duncan

Northwest Power Pool

920 S. W. Sixth Avenue

Room 1210

Portland, OR 97204

J. Hoozen

Bonneville Power Administration

P. 0. Box 3621

Portland, OR 97208

J. Jaksch

Corvall is Environmental

Research Laboratory

U. S. Environmenta]

Protection Agency

Corvallis, OR 97331

M. Katz

Bonneville Power Administration

P. 0. Box 3621

Portland, OR 97208

J. E. Kiley

Bonneville Power Administration

P. 0. Box 3621

Portland, OR 97208

W. Kvarsten, Director

Conservation and Development Commission

1175 Court Street, N.E.

Salem, OR 97301

D. J. Lewis

Pacific Northwest Utilities

Conference Committee

920 S.W. Sixth Avenue

Portland, OR 97204

1. C. Lonsli

Bonneville Power Administration P. 0. Box 3621

Portland, OR 97208 
No. of Copies

F. D. Miller

Oregon Department of Energy

528 Cottage, N.E.

Salem, OR 97310

Maj. Gen. W. E. Pee 1

Division Engineer

North Pacific Division

Corps of Engineers

210 Custom House

Portland, OR 97209

C. H. Watkins

Bonneville Power Administration

P. 0. Box 3621

Portland, OR 97208

\section{WASHINGTON}

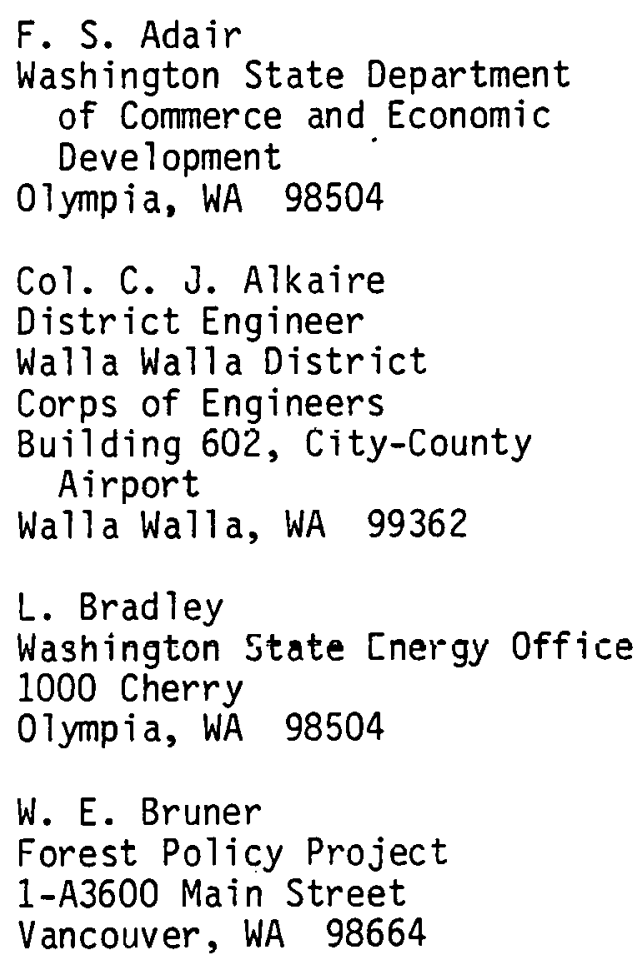

F. S. Adair

Washington State Department of Commerce and Economic Development

Olympia, WA 98504

Col. C. J. Alkaire

District Engineer

Walla Walla District

Corps of Engineers

Building 602, City-County Airport

Walla Walla, WA 99362

L. Bradley

Washington State [nergy Office

1000 Cherry

OTympia, WA 98504

W. E. Bruner

Forest Policy Project

1-A3600 Main Street

Vancouver, WA 98664

No. of

Copies

L. E. Coate

U. S. Environmental Protection. Agency

1200 Sixth Avenue

Seattle, WA 98101

H. G. Curtis

Public Power Council

P. 0. Box 1307

Vancouver, WA 98660

H. C. Elmore

Pacific Northwest Utilities

Conference Committee

P. 0. Box 1231

Wenatchee, WA 98801

M. H. Karr

Pacific Northwest River Basins Commission

1 Columbia River

P. 0. Box 980

Vancouver, WA 98660

N. Lewis

Office of Program Planning and Fiscal Management

State Planning Division

House Office Building

Olympia, WA 98504

B. Pearson

RIS Library

Department of Ecology

01 ympia, WA 98504

R. Polzin

Energy Facility Site

Evaluation Council

820 East Fifth Avenue

Olympia, WA 98504 
No. of

Copies

J. B. Robertson

DOE, Federal Region $X$

Federal Building, Room 1992

915 Second Avenue

Seatt le, WA 98174

E. T. Shaw

Utilities and Transportation

Commission

Highways-Licenses Building

Orympia, WA 98504

M. Walsh

Department of Ecology

State of Washington

Olympia, WA 98504

\section{ONSITE}

DOE Richland Operations Office

P. W. Gottschalk

H. E. Ransom
No. of

Copies

Pacific Northwest Laboratory

W. J. Bair

J. B. Brown

D. B. Cear lock

W. E. Davis

D. W. Dragnich

R. L. Drake

D. R. Drewes

W. J. Eadie

D. L. Hessel (10)

G. B. Long (4)

S. Marks

W. F. Sandusky (3)

W. H. Swift

M. L. Warner

L. D. Williams

G. L. Wilfert

Economics Library (5)

Publishing Coordination (2)

Technical Information Files

Human Affairs Research Center

J. A. Hebert

S. M. Nealey 